\title{
رؤية نقدية للفكر العقلاني في ضوء التربية الإسلامية
}

$$
\begin{aligned}
& \text { إعداد: } \\
& \text { د. بدريه خلف حمدان العنزي } \\
& \text { الأستاذ المساعد في جامعة الإمام محمد بن سعود الإسلامية } \\
& \text { كلية التربية-قسم أصول التربية }
\end{aligned}
$$

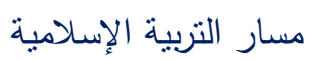




\section{مستخلص البحث}

موضوع البحث: رؤية نقدية للفكر العقلانى في ضوء التربية الإسلامية. هدف الدراسة: إبراز دور العزلة والفكر الفلسفى وتحديد المدرسة الفكرية التي ينتمى لها المعري، وإبراز كيف

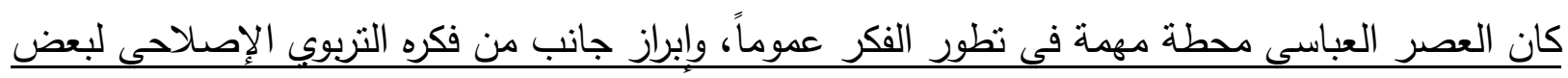

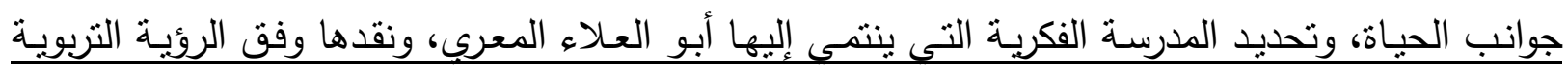
الإسلامية. المقدمة: وتثمل مشكلة البحث، وأهدافه، وأهمية الموضوع، والدراسات السابقة، ومنهج البحث، ومصسادره، وأقسامه، وتخطيطه. الفصل الأول: حياة أبي العلاء المعري. وفيه: المبحث الأول: اسمه وكنيته ولقبه ونسبه. المبحث الثاني: منزلته الثعرية. المبحث الثالث: رحلاته وعزلته ودينه وآثاره وتلاميذه. المبحث الرابع: شيخوخته، وصيته، ووفاته. الفصل الثانى: آراؤه الفلسفية والتربوية ومدرسته الفكرية، وفيه: المبحث الأول: قلق الحياة في أدب أبي العلاء المعري.

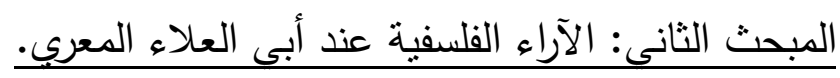
المبحث الثالث: المدرسة الفكرية التي ينتمى لها أبو العلاء المعري ونقدها وفق الروئية الإسلامية. 


\section{Abstract}

Research topic: A critical view of rational thought in the light of Islamic education.

The purpose of the study is to highlight the role of isolation and philosophical thought and identify the school of thought to which Al-Ma'ri belongs. It highlights how the Abbasid era was an important stage in the development of thought in general, and highlighting some of its educational reformist ideas for some aspects of life. Islamic Educational Vision.

Introduction: The problem of research, its objectives, the importance of the subject, previous studies, research methodology, sources, sections, and planning.

Chapter One: The Life of Abu Ala Al Ma'ari. And in it:

The first topic: is his name, his nickname, his surname and his name.

The second subject: His poetic status.

The third topic: his journeys, isolation, religion, traces and disciples.

The fourth topic: his old age, his will, and his death.

Chapter II: His philosophical and educational views and his intellectual school, in which:

The first topic: concern of life in the literature of Abu al-Ala Maari.

The second topic: Philosophical views of Abu al-Ala al-Ma'ari.

The third topic: the intellectual school to which Abu al-'Ala alMa'arri belongs and her criticism according to the Islamic vision.

Conclusion: References. 


\section{الفصل الأول}

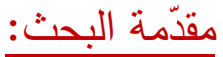

تحرص الأمم المنقدمة على البحث في مكتسباتها الفكرية التي قدمها العلماء والمفكرون عبر تاريخ إنهاء

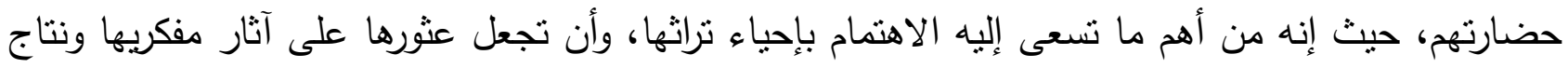

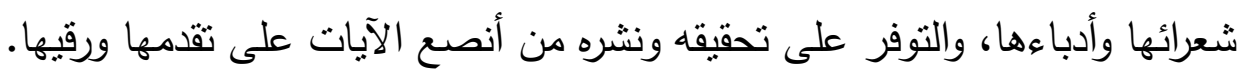
وموضوع هذا البحث هو خطوة في هذا الميدان ،حيث ستتناول فيه الباحثة شخصية فكرية لها نها نتاجها

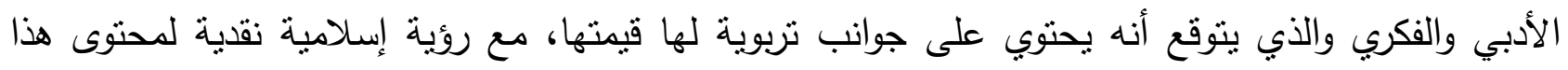

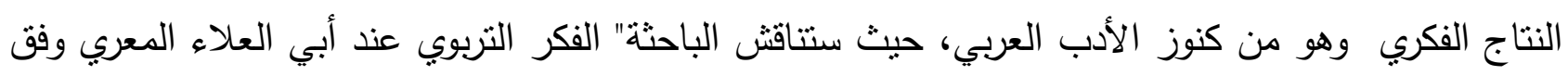

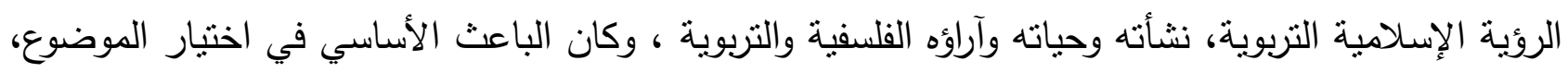

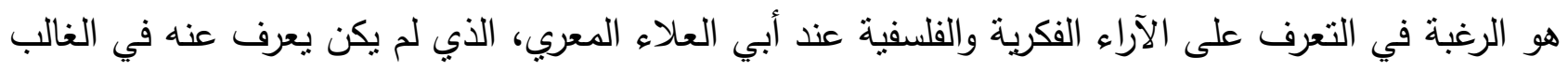

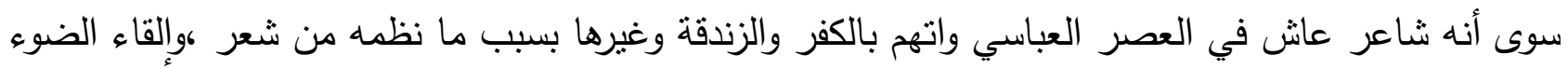

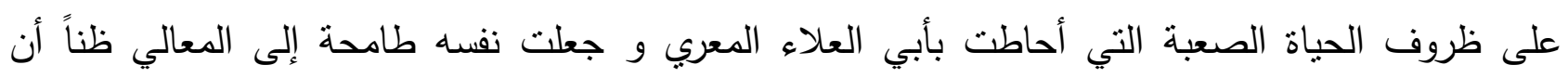

\section{أريدُ عَلَّاتِ المراتب ضِّلةً}

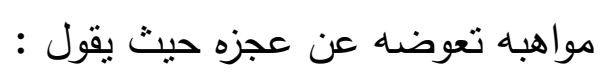

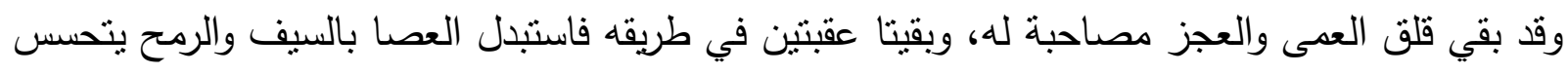

بها الطريق كي لا يصطدم بالبشر والدجر يقول:

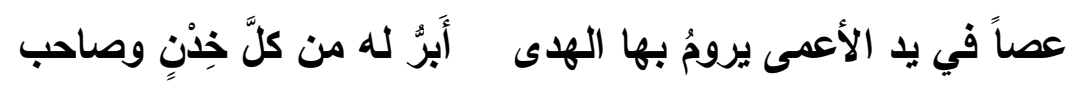

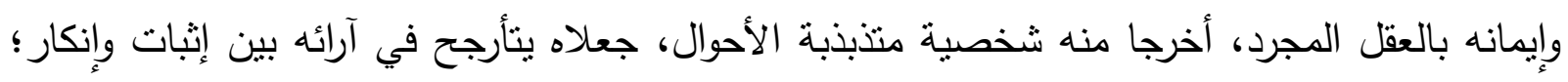

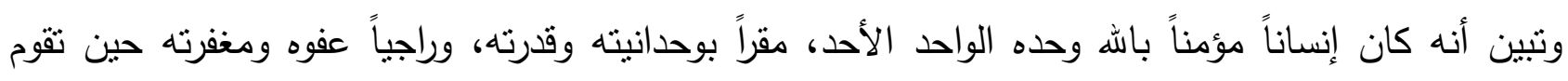

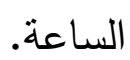

أصيب أبو العلاء المعري بالجدري وهو لم يتجاوز الرابعة من عمره فكف بصره، ولم تمنعه عاهته عن التهب الدرس فدرس العلوم من فقه ونحو وأدب، وجعل يتابع بنهم كتب الأدب القديمة من أدبية وتاريخية، وقال التبال الثعر

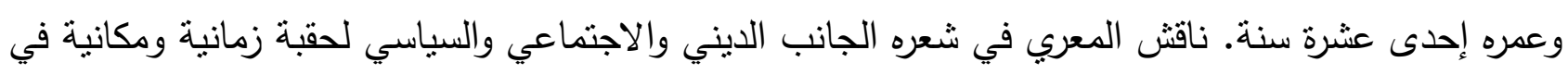
الثاريخ العربي والإسلامي، وترك المعري تراثا في الثعر والأدب والفلسفة.

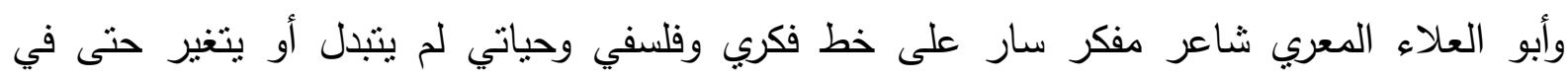

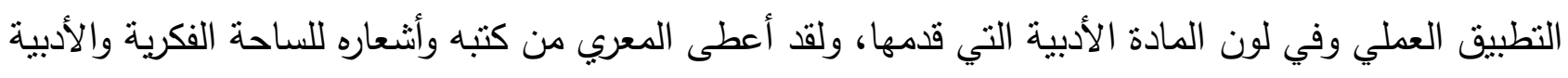

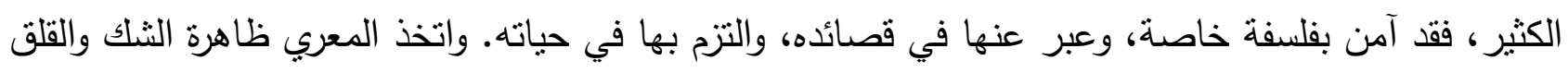

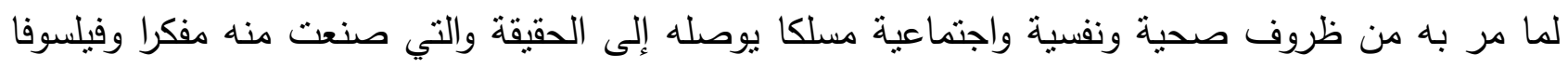


وناقدا لما يدور حوله من الحياة من خلال أشعاره ، وذلك من خلال منهجه والذي جمع فيه بين التقليد والتجديد، فأكثر قصائد ديوان ( سقط الزند ) تتهج النهج التقليدي للقصيدة العربية، ونجده جاريا على سنن الأقدمين من فن الوقوف على الأطلال البدوية الجزلة، و المعاني الفخمة، واتخذ من الثعر العربي القديم مصدرا يستمد منه

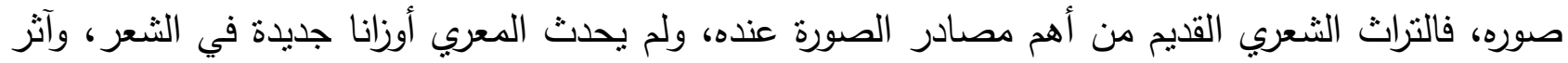
في الأغلب شعراء العربية من سابقيه من أوزان، ودرج على الطريقة التي درج عليها الثعراء الجاهليون فنظم في

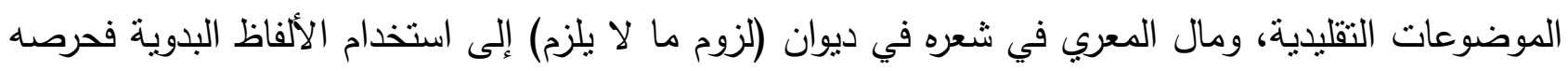

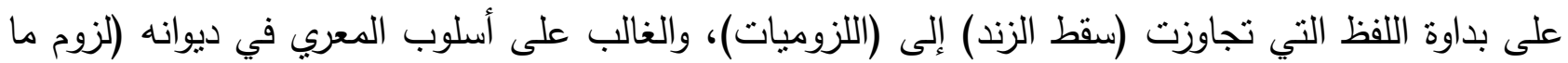

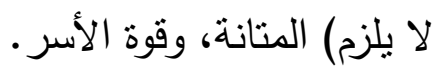

وقد قامت الباحثة في هذا البحث بما تسنطيع من جهد بذكر كل ما لمحته في شعر أبي العلاء المعري

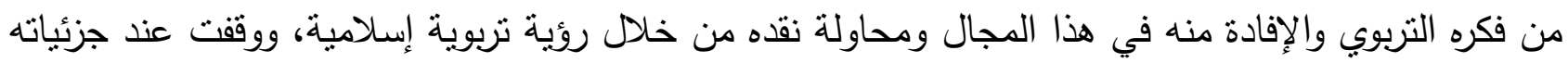
ودقائقه التي رأت أن فيها نفعا لهذا البحث وخدمة لخطته التي جاءت في ثلاثة فصول تحوي سبعة مباحث

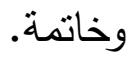
أما الفصل الأول، فتحدثت فيه الباحثة عن مشكلة البحث، وأهدافه، وأهمية الموضوع، والدراسات السابقة، ومنهج البحث، ومصادره، وأقسامه، وتخطبطه.

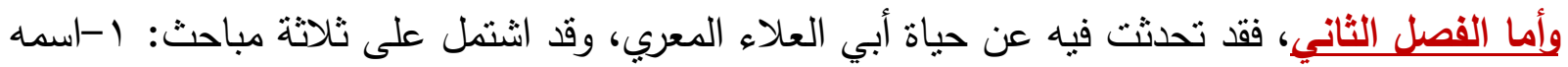
وكنيته ولقبه r-ولادته ونشأته وزهده r-رحلاته وعزلته ودينه وآثاره وتلاميذه.

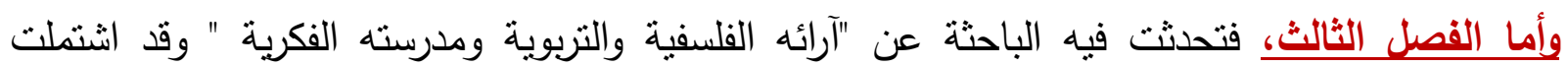
مباحثه الثلاثة على: ا-قلق الحياة في أدب أبي العلاء المعري. ب-ظاهر التقليد في شعر المعري، الآراء الفلسفية عند أبي العلاء المعري. ب-المدرسة الفكرية التي ينتمي لها أبو العلاء المعري ونقدها وفق الروئية التربوية الإسلامية.

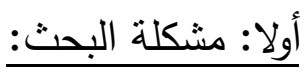

الناظر في حياة أبي العلاء المعري ينبين له انفراده في منهج مختلف في التفكير والذي كان محط نقد وتحليل لما تمتع به من آراء فلسفية حتى صار مدرسة فكرية تعرضت للنقد تارة وللنقض تارة أخرى، مرورا

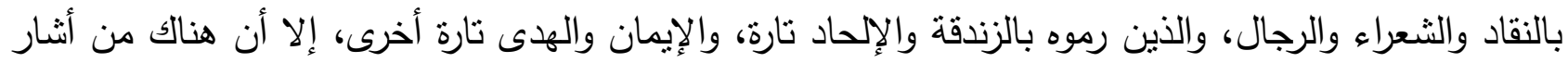

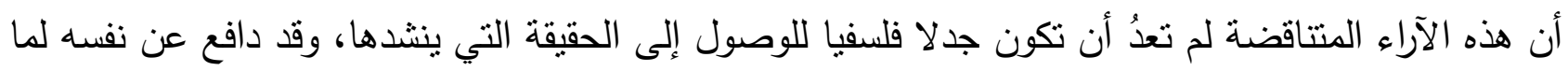

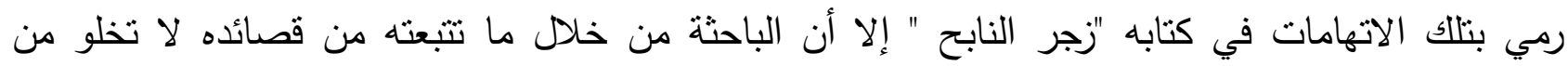
إثنكالات في فكره العقدي، والضبابية التي يعاني منها . 
ومع ذللك يعد أبو العلاء المعري آخر عمالقة الشعر القديم فقد ارتفع بشعره إلى مسنوى من الجزالة عن طريق المزاوجة النادرة بين الفن والفلسفة، فكان شعره طريفا شكلا ومحتوى، ولعل تميزه من - بين أدباء العربية وعدد من المحثثين - بالنزعة التأملية، وموقفه من الحياة والناس إلى جانب قلة اهتمام القدامى والمحدثين بأدبه

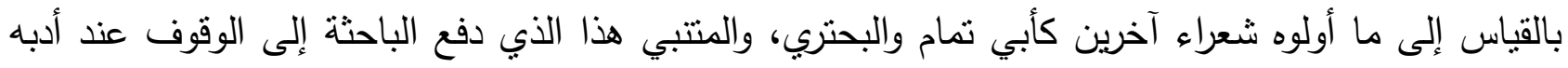

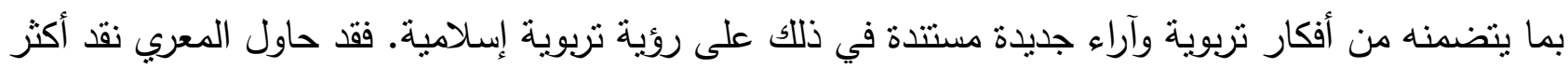

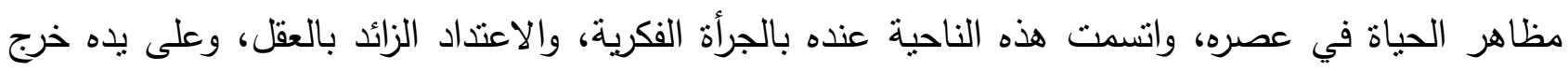

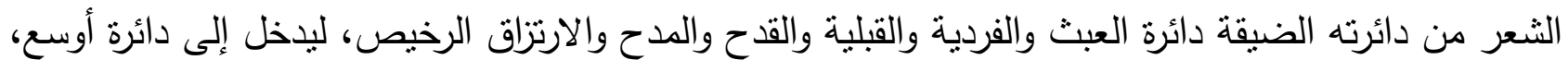

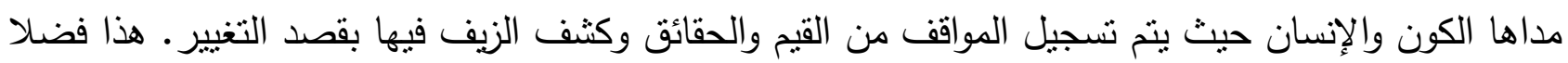
عن نقد أسس الثقافة العربية نقدا يصل إلى الدعوة إلى مراجعة العقل العربي، فمن شعره في اللزوميات:

\section{لقد صدئت أفهام قوم فهل لها}

فلم يعد الثعر في مفهوم أبي العلاء المعري إذن وسيلة للعيش الرخيص أو الكذب المغلف أو الثتن، بل

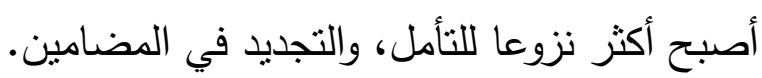
لذلك رأت الباحثة اختياره موضوعا لهذا البحث، كون منل هذه المضامين قد تتري التربية في عدد من

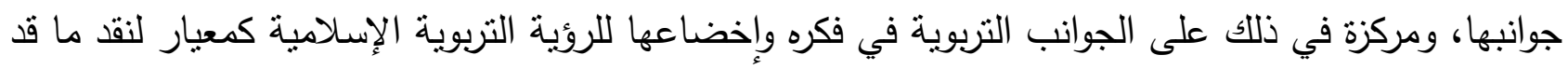
يرد عليها من نقد في مجال الفكر التربوي.

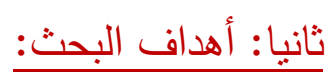

إن التغيرات الكثيرة التي مرت بحياة الثاعر المعري من العمى والرحلات والعزلة وقلق الحياة والتحول

للمسلك الفلسفي الفكري، شكلت منه شخصية مختلفة، تحتاج معها للوقوف على مدرسته الفكرية التي استقى منها أدبه ونهجه ومن ثم نقد رؤيته الفكرية بما يتوافق والروئة الإسلامية وما في هذا الفكر من مضامين تربوية، لفيها ولذلك يهدف هذا البحث إلى: ـ إبراز دور العزلة والفكر الفلسفي والذي دفعه للتعبير عن صلته باله والذات الإلهية والوجود بأبيات أدت به إلى اتهامه في جوانب عقدية ووجود خلل عنده في هذا الجانب نظرا لأنها تخالف المعهود من ظاهر

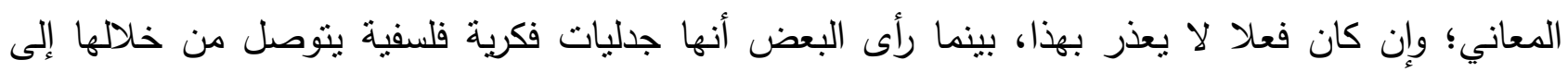

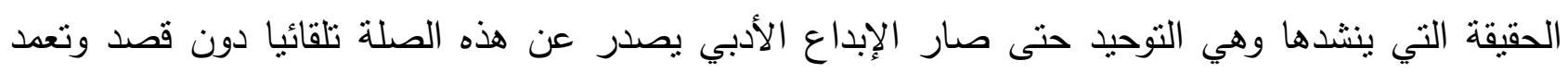
وتكلف.

- تحديد المدرسة الفكرية التي ينتمي لها المعري من مؤيدين ومعارضين وترجيح القول فيه بالأدلة، ونقدها وفق الروئية التربوية الإسلامية. 
- إبراز كيف كان العصر العباسي محطة مهمة في تطور الفكر عموماً، فيه عرف انطلاقته الكبرى، ومن خلاله بلغ ذروة عطائه فلسفيا وعلميا وأدبيا. تأثز بالمتنبي في مطلع حياته كما في ديوانه الأول (سقط الزند)

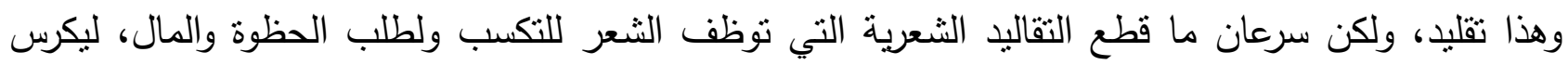
شعره للتعبير عن تجربته الخاصة وتأملاته ونظرته للحياة والناس والوجود وهذا تجديد كما في ديوانه الثاني (لزوم ما لا يلزم)، وهكذا يكون للعصر تنأثير كبير في الفكر .

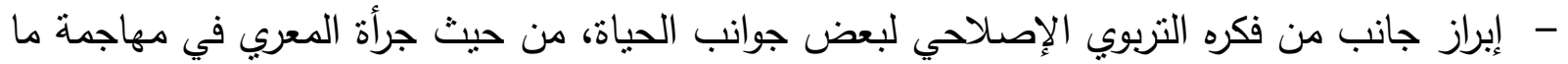
يراه فاسدا، وصرفه الثعر إلى مواضيع إنسانية أخلاقية، وانعدام الهوى بين أقواله وأفعاله وثقافته الواسعة وبعد نظره، وشاعريته المميزة، ثم تحليل ذلك وفق الروية التربوية الإسلامية.

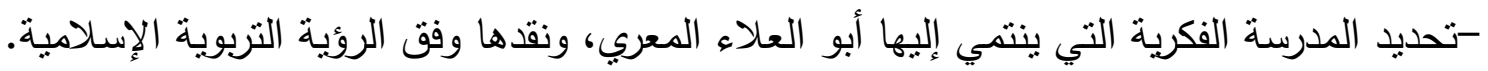
ثالثا: أهمية موضوع البحث:

يمكن تقسيم أهمية هذه الدراسة في جانبين:

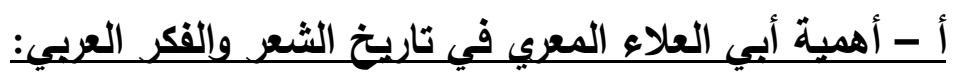

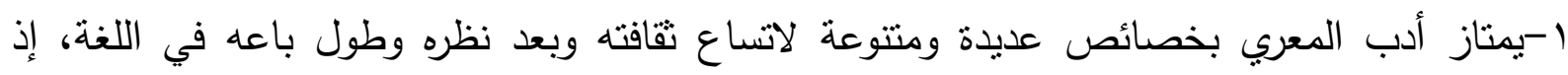
يلاحظ قارئ نتاجه اهتمامه بالناحية اللفظية في شعره ونثره على حد سواء. ץ-ترك أبو العلاء المعري ثراثا على مر العصور، وكان لهاه أكبر الأثر في فكر كثثر من المفكرين والعلماء والأدباء، ويرتبط هذا ارتباطا مباشرا بالفكر التربوي وما يحتويه من مضامين.

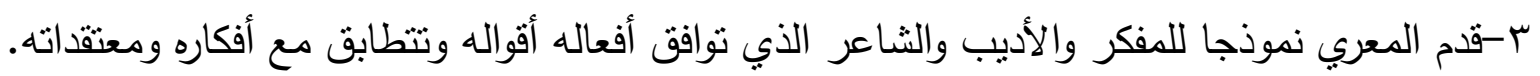
ه-يعد المعري شخصية مختلفة في الأدب والفكر العربي شكلت انقلابا على التقافة السائدة في عصره والتقاليد التي أرساها من سبقوه لذا كان فكره التربوي جدير بالوقوف والتأمل. צ-كرس المعري شعره للتعبير عن تجربته الخاصة وتأملاته ونظراته في الحياة والناس والوجود، وهي لوني نظرات وتأملات أعلت من قيمة الأدب والفكر من عدة جوانب، إلا أن اعتماده على تحليله العقلي أوقعه في

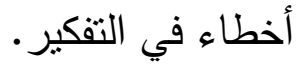
V-تعود أسبقية نقد العقل والواقع التربوب العربي لأبي العلاء المعري في القرن الخامس الهجري، حيث نقد

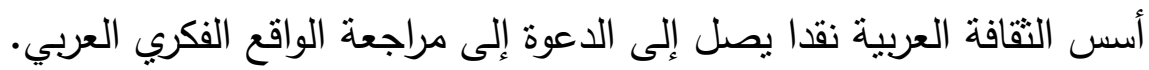
ب - أهميته في الدراسة الحالبة:

أولا: لم يدرس الموضوع دراسة مباشرة بهذه الصيغة التي قدمتها الباحثة على الرغم من أنها وجدت حديثا

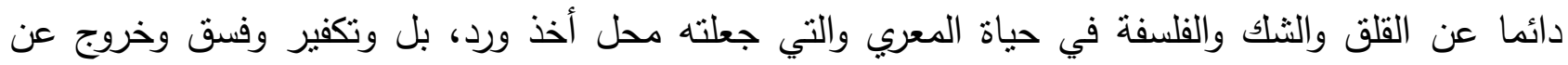

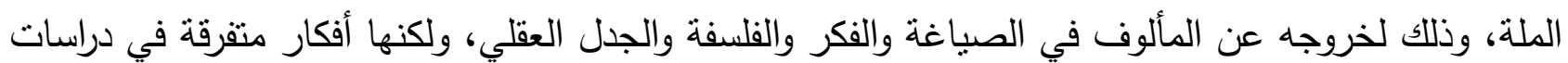


أخرى مثل الحيرة والحكمة وغير ذلك من القضايا العامة دون أن تكون دراسات مختصة في نقد مدرسته الفكرية وفق الروية التربوية الإسلامية.

ثانيا: تبرز أهية البحث في تغيير الثعر العربي على يد أبي العلاء المعري على مستوى الأغراض، إذ إذها أصبح مع المعري شعر الحكمة والفلسفة ونقد رجال السياسة والأمراء نقا بناء غير هجائي، فضلا عن الدعوة إلى العقل بالأسلوب الثعري، بل إن البحث سيبين كيف اعتمد المعري الثُعر لينقد الفكر والعقل العربي وما آل إليه من خرافة وأساطير، وهو أمر غير معهود في شعر يسيطر عليه الغزل والمديح والتملق، بل ربما سخرية أبي العلاء من شعراء المديح في (رسالة الغفران) وعدهم شعراء مديح وتملق للحكام بكل هذه الأسباب. لإيعا: الدراسات السابقة:

من خلا الاطلاع الذي قامت به الباحثة على الدراسات السابقة، ذات العلاقة بموضوع الدراسة الحالية،

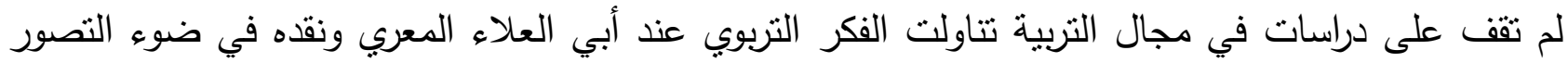
الإسلامي، كان منها دراسات قدمت في تخصصات علمية أخرى غير تربوية، كدراسة كريم (Tr (هـ)، بعنوان: شعر المعري من منظور القراءة والتأويل، في جامعة أم القرى، ودراسة أخرى قدمها بوعافية (1 . ـ ام) بعنوان: الاغتراب في شعر أبي العلاء المعري في جامعة محمد بوضياف بالمسيلة في الجزائر . وأغلب ما كتب عن أبي العلاء المعري كان كتبا مؤلفة وليس أبحاثا علمية منها:

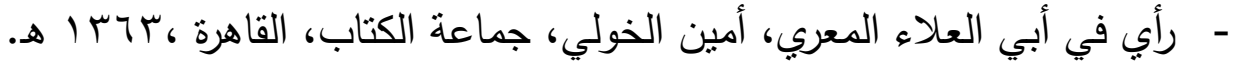
- الحياة الإنسانية عند أبي العلاء المعري، عائشة عبد الرحمن، دار المعارف، مصر، ـ ؟ 9 م.

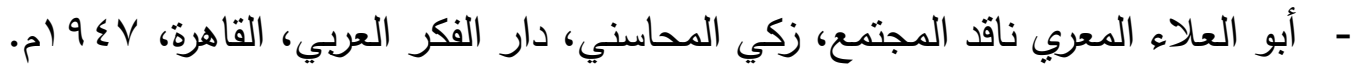

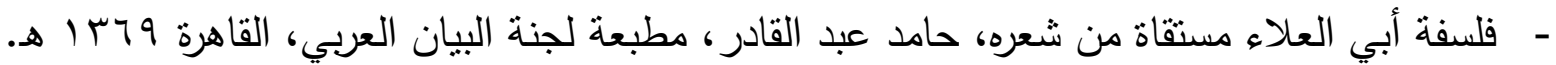
- - أبو العلاء المعري آراؤه في لزومياته، كمال اليازجي، لجنة التأليف المدرسي، لبنان، ـ19 19 م.

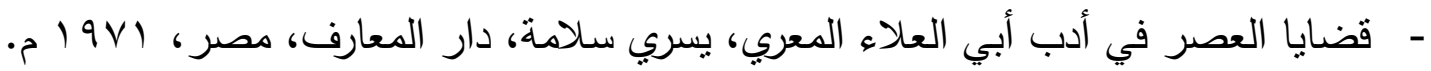

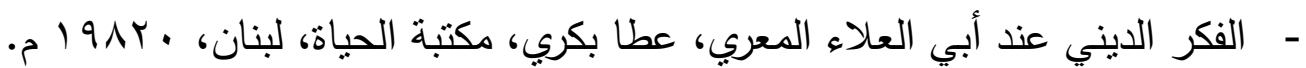
- الفكر والفن في شعر أبي العلاء المعري، صالح حسن اليظي، 19191 م.

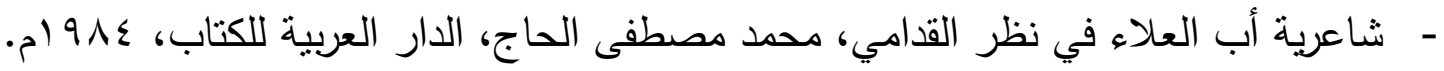

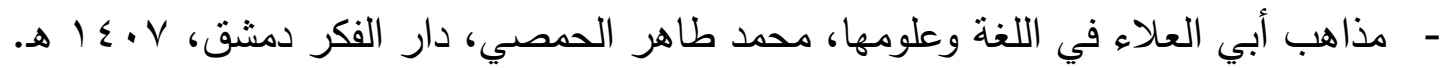
- المعري ذلك المجهول رحلة في فكره وعالمه النفسي، عبد الله العلايلي، دار الجديد، لبنان، 1990 م. - النزعة الفكرية في اللزوميات، خليل إبراهيم أبو ذياب، الثركة العربية للنشر والتوزيع، مصر، 990 (م.

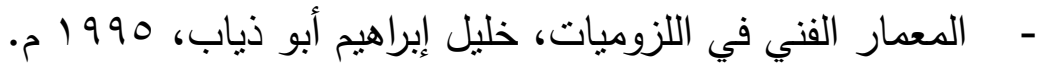
- فلسفة الدين والحياة عند أبي العلاء المعري، أحمد على إبراهيم، دار الثؤون الثقافية، 9 ـ . ب م. م. 
ومن هنا نلحظ أن معظم الكتب والبحوث والدراسات جاءت دفاعا عن أبي العلاء المعري وإثبات أثزر

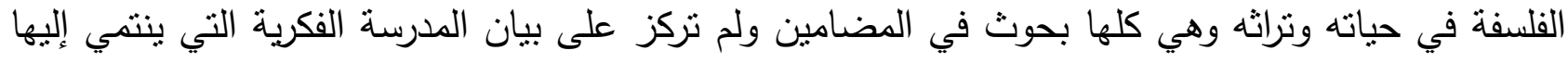

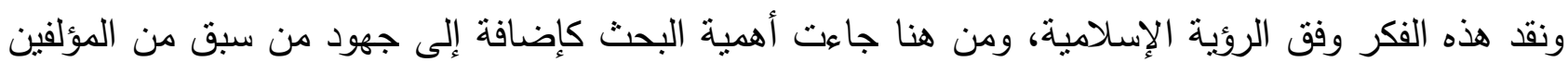

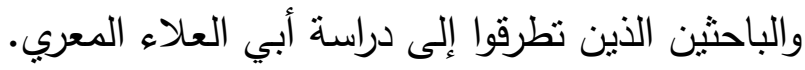

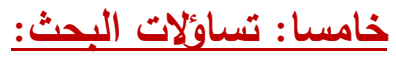
جاءت فصول البحث ومباحثة للإجابة على عدة تساؤلات هي في ذاتها لب البحث وأساسه وهي: 1- ا-ما العوامل التي أثرت في تثكيل شخصية المعري؟ r-ما أثر العزلة والقلق والثكك في حياة المعري الفكرية؟

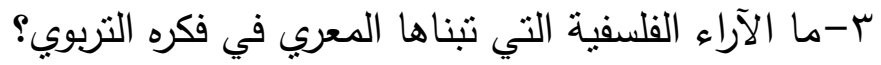

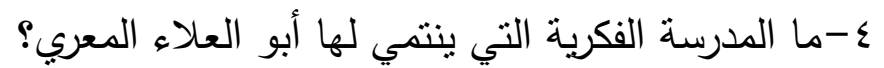

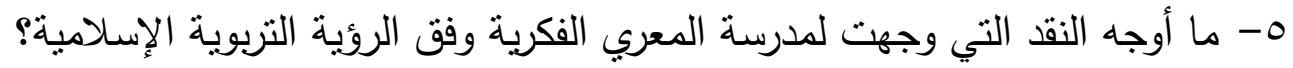
ساسا: منهج البحث: ماته يعتمد البحث المنهج الوصفي التحليلي، فهو من ناحية يقدم عملا وصفيا، ومن ناحية أخرى يرمي إلى غاية تحليلية.

قامت فيه الباحثة باستعراض مظاهر القلق والثثك في حياة الثناعر، بالإضافة إلى آرائه الفلسفية الني

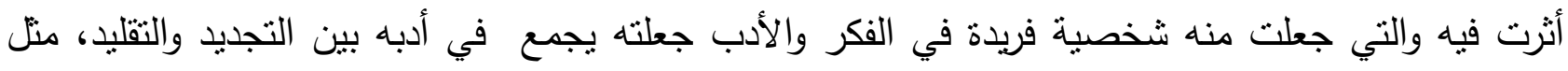

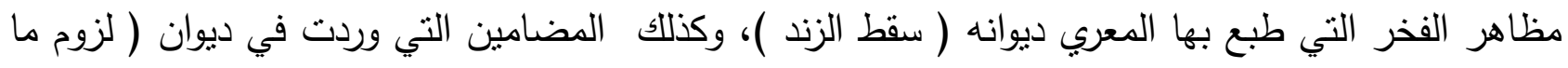

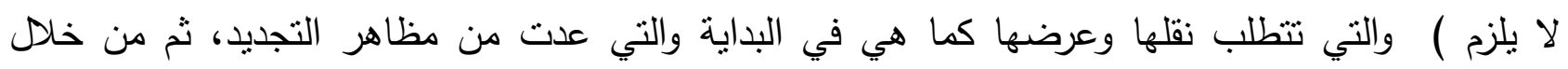
التحليل واستعراض الفكر التزبوي الذي تنباه المعري نبين مدرسته الفكرية التي ينتمي إليها ونقدها وفق الروئية التزبوية الإسلامية. سابعا: مصادر البحث: تقع أثعار أبي العلاء المعري في مجموعتين: الأولى: شعر الصبا والثباب وهي التي سماها (سقط الزند).

والثانية: اللزوميات وهي التي سماها (لزوم ما لا بلزم). وستعتمد الباحثة هذين الديوانين وتجعهما مصدرين أساسيين للبحث، وأما عن بقية أشعار المعري فإنها

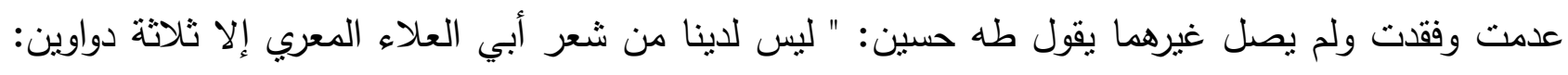

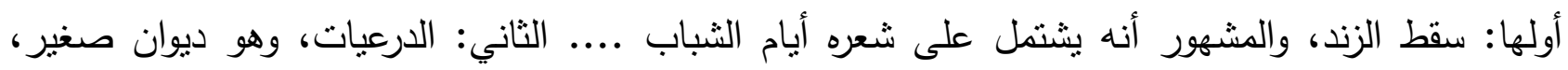


يشتمل على أنتعار وصفت فيها الدرع خاصة، وقد طبع بمصر ملحقا بسقط الزند ... الثالث: اللزوميات: وهي أكبر الدواوين الثلاثة ". نثامنا: أقشسام البحث: المقدمة: - منام وتتمل مشكلة البحث، وأهدافه، وأهمية الموضوع، والدراسات السابقة، ومنهج البحث، ومصادره، وأقسامه، وتخطيطه.

الفصل الأول: حياة أبي العلاء المعري. المبحث الأول اسمه وكنيته ولقبه ونسبه. المبحث الثاني: منزلته الثعرية. المبحث الثالث: رحلاته وعزلته ودينه وآثاره وتلاميذه. المبحث الرابع: شيخوخته، وصيته، ووفاته.

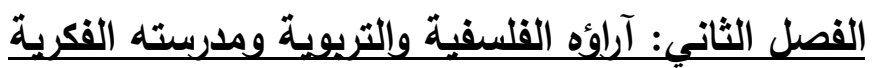
المبحث الأول: قلق الحياة في أدب أبي العلاء المعري.

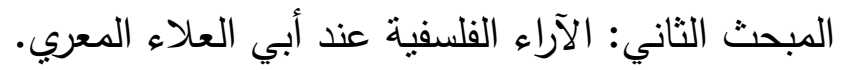
المبحث الثالث: المدرسة الفكرية التي ينتمي لها أبو العلاء المعري ونقدها وفق الرؤية الإسلامية. الخاتمة: والمراجع. 


\section{الفصل الثاني: حياة أبي العلاء المعري \\ المبحث الأول: اسمه وكنيته ولقبه ونسبه}

أولا: اسمه: أحمد بن عبد الله بن سليمان: ابن محمد بن سليمان بن محمد بن سليمان بن داود بن المطهر بن

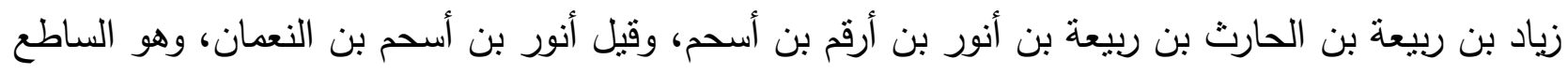

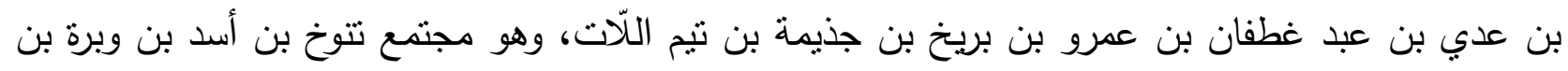

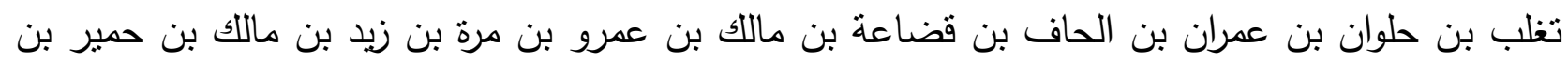

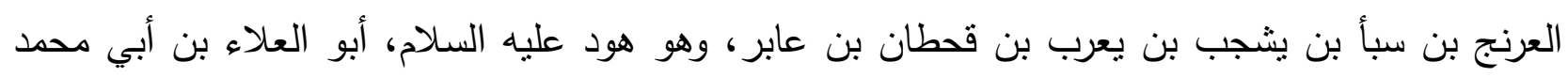
التنوخي المعري (')

يقول المرحوم: أحمد تيمور باشا: (هكذا ساق نسبه ابن خلكان، وهو أصح ما وجد بالمعارضة على ما

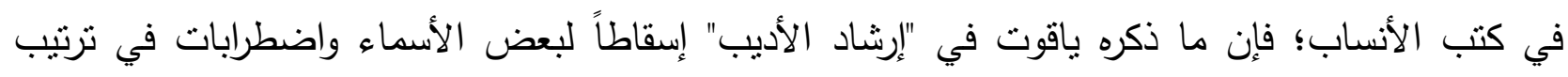
بعضها، فاعتمدنا على رواية ابن خلكان بعد تصحيح ما حرف منها، فإن خزيمة بن تيم الله جاء في النسخة لإنة

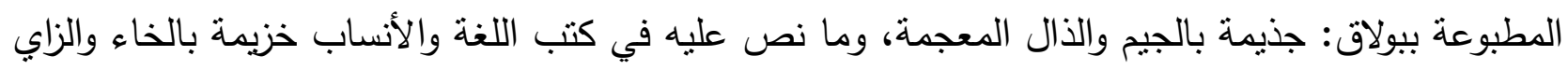
مصغراً، وتيم الله بن أسد هكذا في جميع ما وققنا عليه من الكتب، وجاء به أبو العلاء في سقط الزند تيم

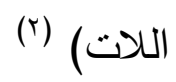

(شاعر وفيلسوف، ولد ومات في معرة النعمان، كان نحيف الجسم، أصيب بالجدري صغيراً فعمي في السنة

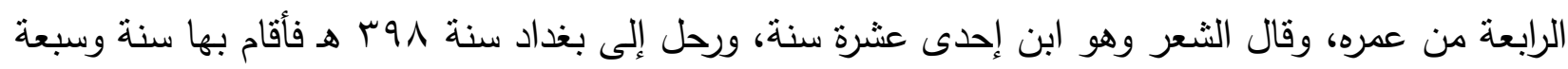

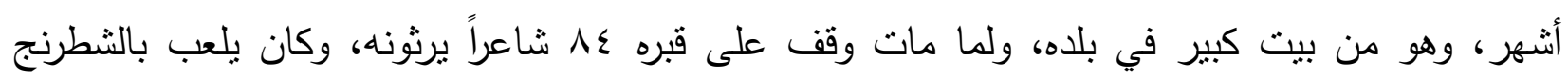
والنرد، وإذا أراد التأليف أملى على كانبه علي بن عبد الله بن أبي هاتش، وكان يحرم إيلام الحيوان، ولم يأكل

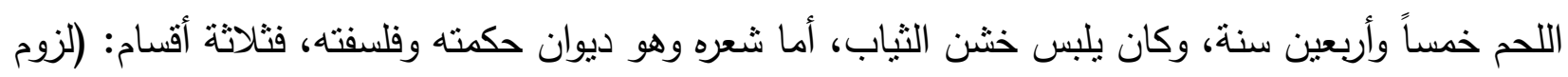

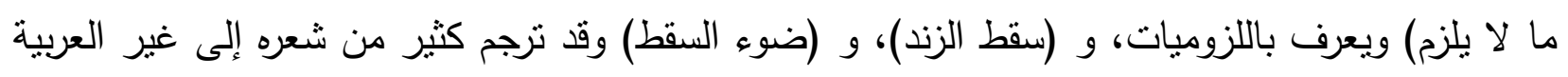

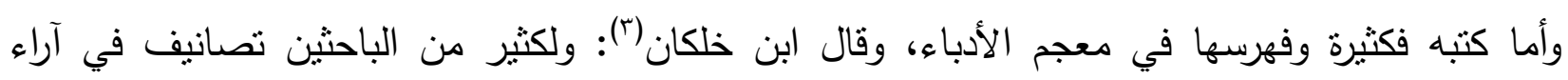

(1) عمر بن أحمد بن هبة الله بن أبي جرادة العقيلي، كمال الدين ابن العديم (. • (17هـ، بغية الطلب في تاريخ حلب،

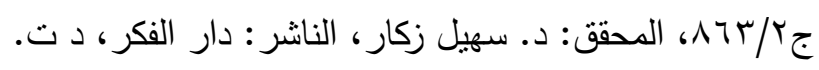
(Y) أحمد تيمور باشا، أبو العلاء المعري، نسبة وأخباره، وشعره، ومعتقده، صدّ، مطبعة لجنة الثأليف والترجمة والنشر بالقاهرة،

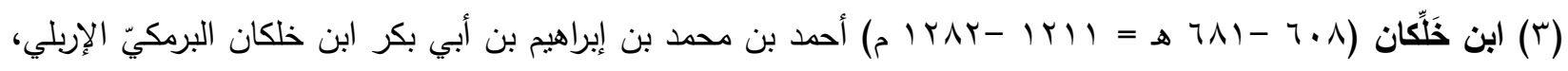

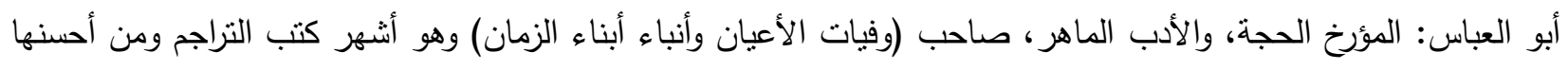


المعري وفلسفته، من تصانيفه كتاب (الأيك والغصون) في الأدب يربو على مائة جزء، (تاج الحرة) في النساء وأخلاقهن وعظاتهن، أربع مائة كراس، و (عبث الوليد) شرح به ونقد ديوان البحتري، و و (رسالة الملائكة) صغيرة، و (رسالة الغفران)، و (الفصول والغايات)، و (رسالة الصاهل والثناحج) ( ('). ثنانيا: كنيته ولقبه ونسبه: كنيته أبو العلاء (ז)، ولقبه المعري، وكانت ونهيه (كنيته أبو العلاء بالفتح والمد إلا أن الناس كانوا بنطقون بها مقصورة في عصره، كما قال:

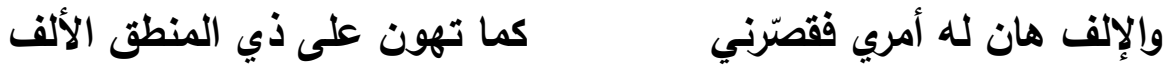

وقد شنع على أبي الحسين النكتي البصري وهو من أصدقاء شيوخه في تسميته إياه محمداً بدل أحمد وأبا

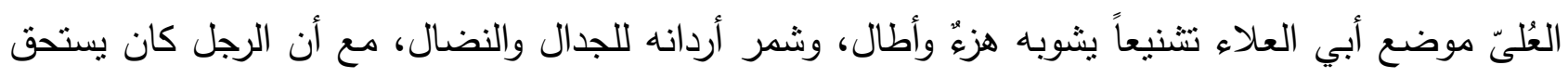

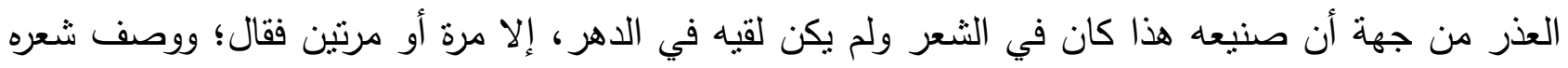

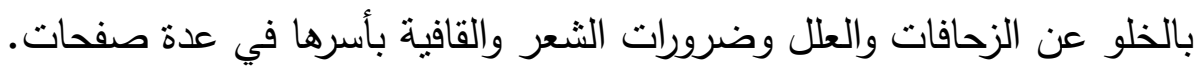

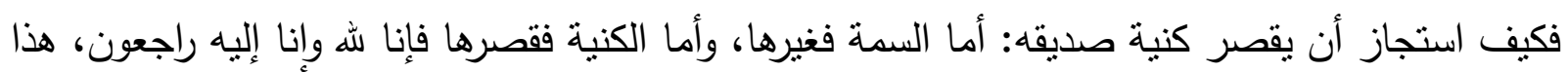
أمر من أمر اله لبس هو من ضعف الثاعر ولا وهن القائل ولكنه من سوء حظ لمن خوطب والاتفاق الرديء

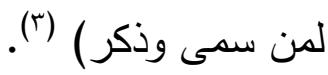

\section{المبحث الثثاني: ولادثة ونشأنه:}

أولا: ولادته:

ثمة اختلاف بين مولده على اختلاف الروايات التي وردت من خلال استقراء الباحثة للمؤلفات التي تكلمت عن أبي العلاء العري من قريب أو من بعيد.

ضبطا وإحكاماً، ولد في إربل (بالقرب من الموصل على شاطئ دجلة الشرقي) وانتقل إلى مصر فأقام فيها مدة، وتولى نيابة

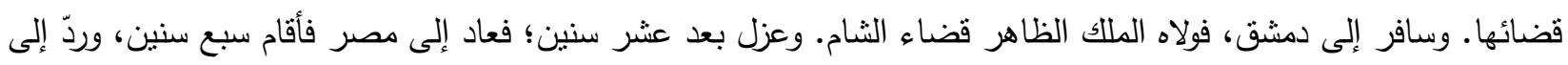

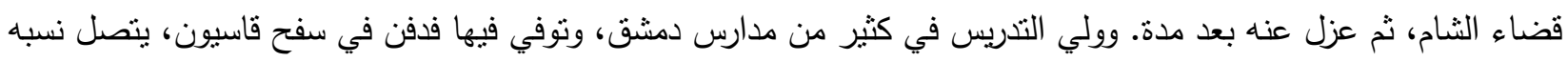

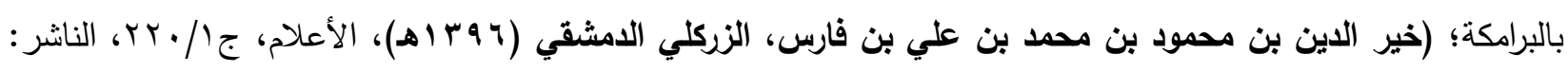

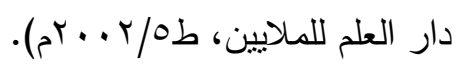

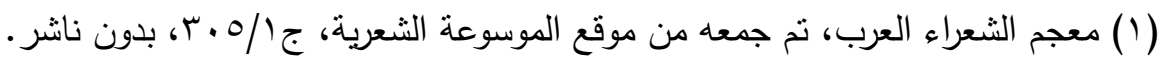

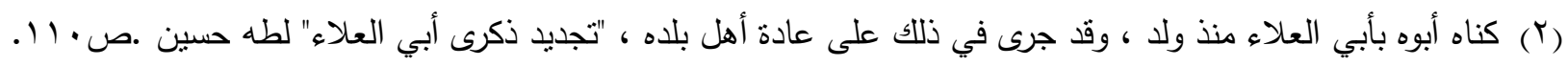

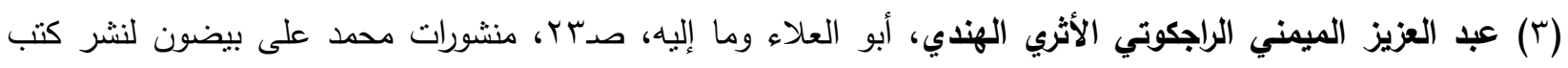

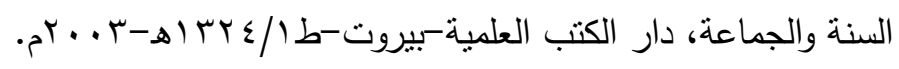




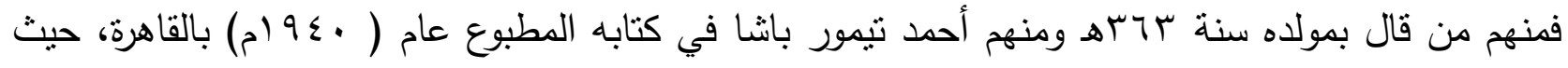

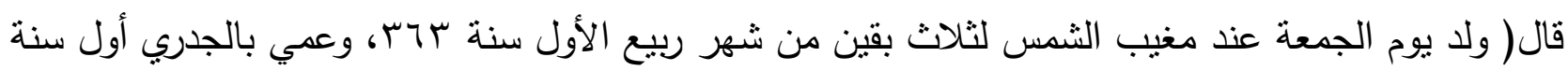
VT Vا، غشي يمنى عينية بياض، وذهبت اليسرة حملة، وكان يقول لا أعرف من الألوان إلا الأحمر، لأنهم ألبسوني حين جدرت ثوبا معصفرا، لا أعقل غير ذللك، وقال في إحدى رسائله إلى داعي الدعاة: (وقد علم الله

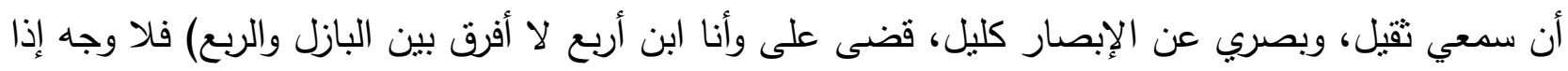
لمن زعم أنه ولد أكمه. وحكى السلفي عن أبي محمد الإيادي أنه دخل مع عمه على أبي العلاء يزوره، فرآه قاعداً على سجادة لبد وهو

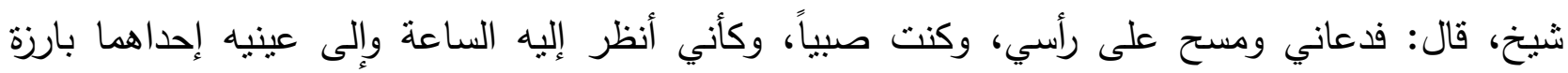

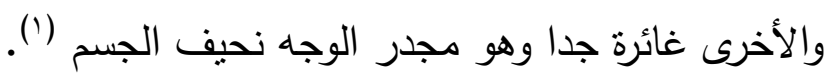
ويقول ابن العديم (؟): (كان مولذُه بمعرّة النعمان في الثامن من شوّال (r) سنة سبع وتسعين وثلاثمائة، وله

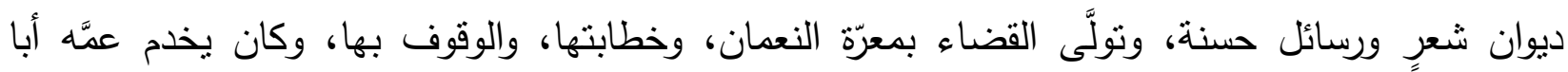
العلاء، ويعلّلّه في مرضه. فقال فيه أبو العلاء (\&):

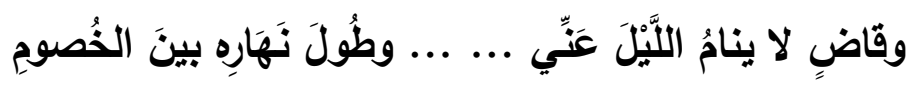

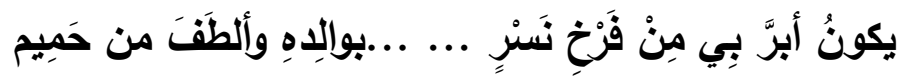

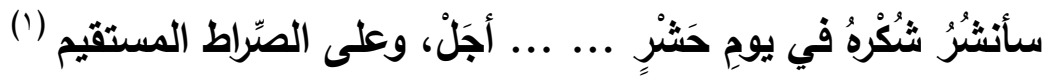

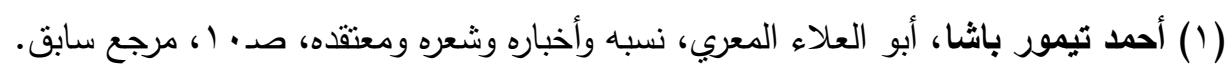

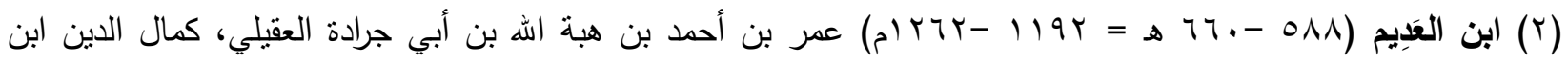

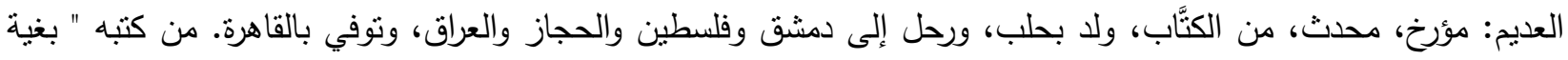

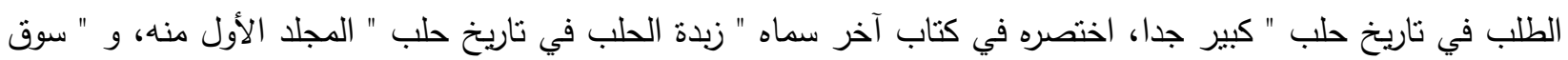
الفاضل " رأيت منه مجلدين في مكتبة عارف حكت بالمدينة، و " الدراري في الذراري " و "وصف الطيب" رسالة، و " الأخبار

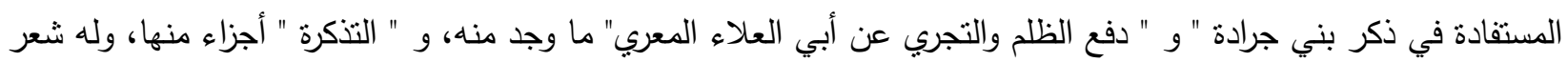

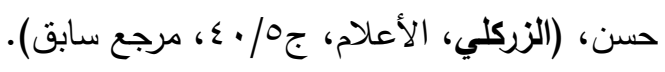

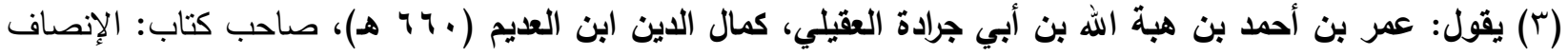

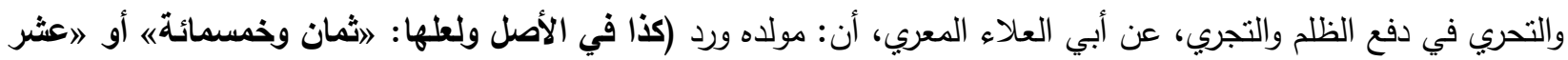

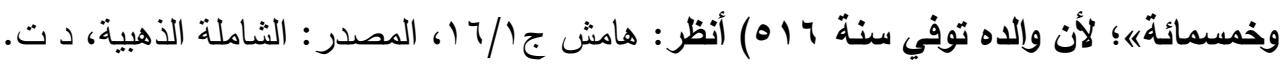

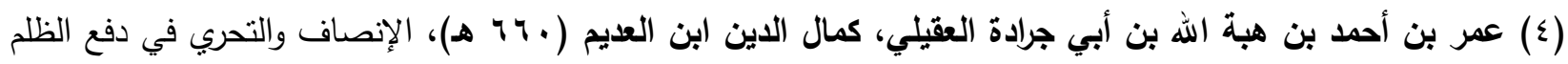

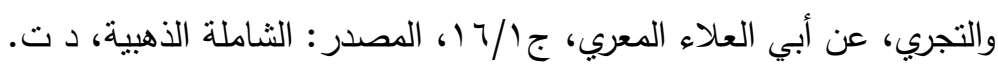


يعتبر أبو العلاء المعري من المشاهير الذين التبس تاريخ ميلادهم؛ ولذلك تجد المؤرخين ما يختلفون

$$
\text { في تعيين مولده. }
$$

إلا أنهم قد أجمعوا على وقت الولادة من النهار ، فقالوا كان ذللك عند مغيب الثمس وأجمعوا على يوم

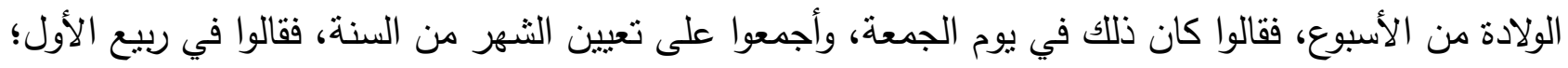

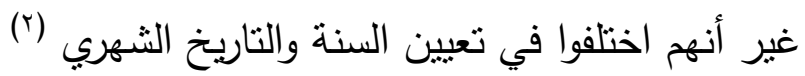
أما القول الذي أيده ابن العديم على أن أبا العلاء ولد في المعرة عند غروب الثمان الثمس من يوم الجمعة

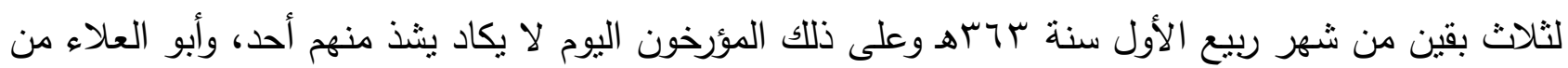

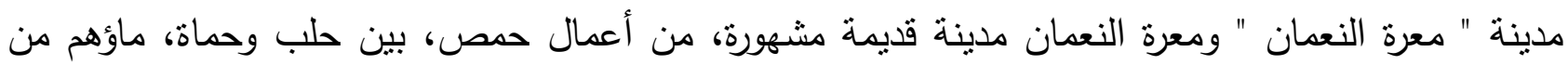

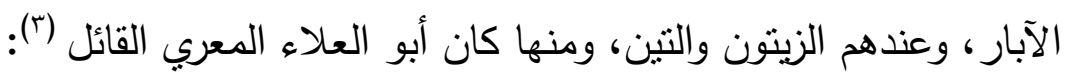

\section{فيا برق ليس الكرخ داري وإنما

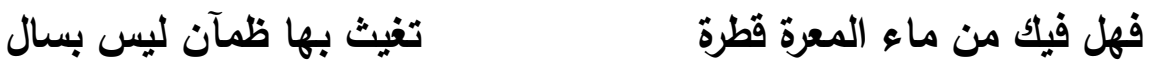

والذي يتضح للباحثة: خلاف ما قاله ابن العديم، فلم تتفق الروايات على نفس اليوم والثهر وإنما تباينت بدليل

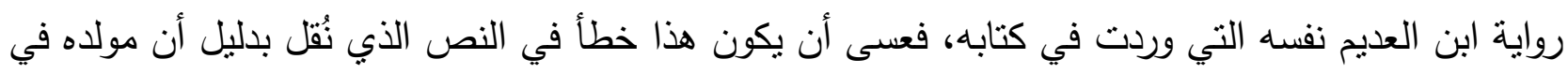
شهر ربيع الأول هو الأكثر عند العلماء المعتبرين لا سيما ياقوت الحموي في معجم البهن البلدان.

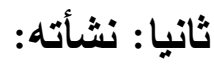
نشأ أبو العلاء في أسرة تشتغل بالعلم والأدب، أبوه عبد الله بن سليمان وينتهي نسبه إلى قضاعة ثم

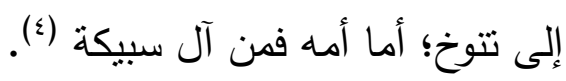

وبيت أبي العلاء من بني سليمان بن داود بن المطهر ، سليل الساطع، ((وهو بيت علم وفضل ورياسة)) وفيهم يقول ابن العديم مؤرخ حلب: ((وأكثر قضاة المعرة وفضلائها وشعرائها وأدباءها من بني سليمان)).

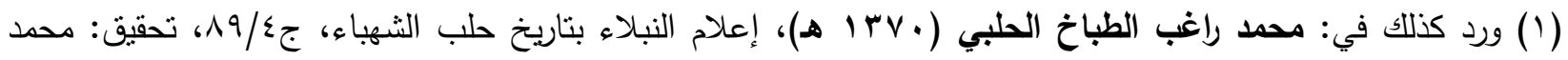

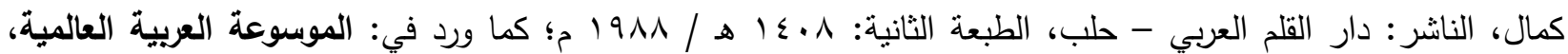
صدا11

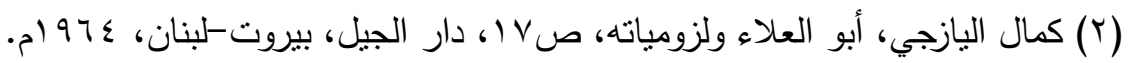

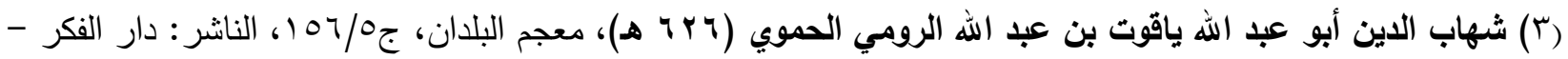


في هذا البيت الكريم الماجد، ولد أبو العلاء، ومن تلك السلالة المعرقة في الفضل والعزة والعلم والأدب تلقى ميراثه. كان عجبا في الذكاء المفرط والحافظة، لا يكاد ينسى شيئا مما يمر بسمعه، وقال الثعر في حداثته.

ولما كبر أبو العلاء، ووصل إلى سن الطلب، أخذ العربية عن قوم من بلده، كبني الكوثز، أو من يجري

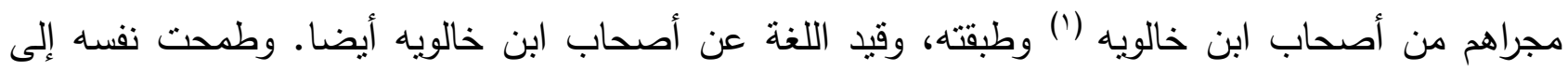
الاستكثار من ذلك؛ فرحل إلى طرابلس الثام، وكانت بها خزائن الكتب قد وقفها ذو اليسار من أهلها، ثم رحل

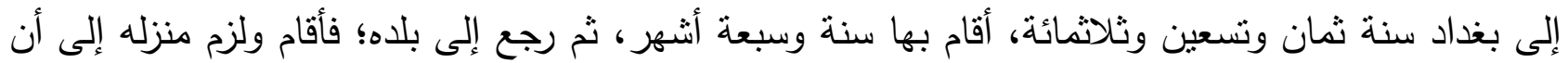

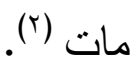

\section{المبحث الثالث: حياته ورحلاته وعزلته ودينه وآثاره}

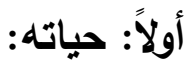

لو نظرنا إلى( العوامل البيئية التي أحاطت بتلك الثخصية، وتعهدت تتمية موهبتها، وإنضاج قدرتها ، وبلورة

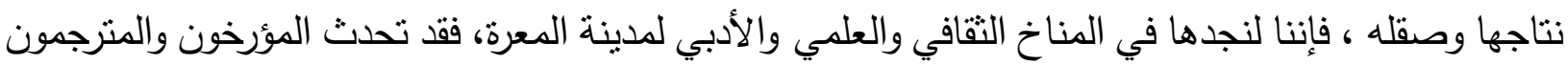
عن بلدة أبي العلاء فقالوا بأنها قد حظيت بنخبة طيبة من الأدباء والعلماء، وأنها من اكثر مناطق العرب منابه مناقباً

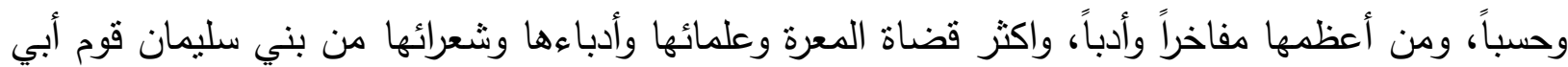
العلاء، فهو من بيت رياسة وعل ، وأبوه من العلماء، وجده، وأبو جده، وجد جده، كلهم تولوا قضاء المعرة،

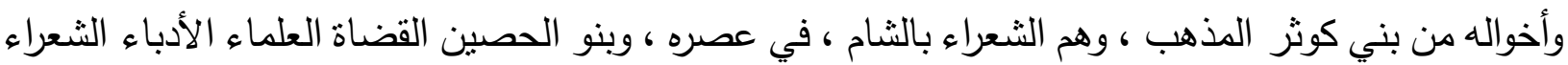

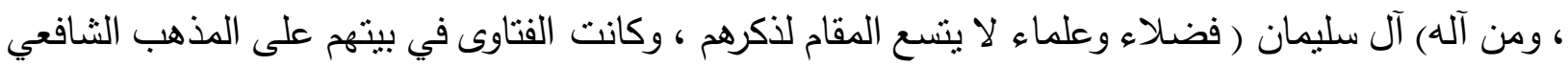
اكثر من مئتي سنة ، وكان لهذا الميراث العلمي أثنه في تربية المعري ، فقد استطاعت أسرته أن تهيئ له قسطاً

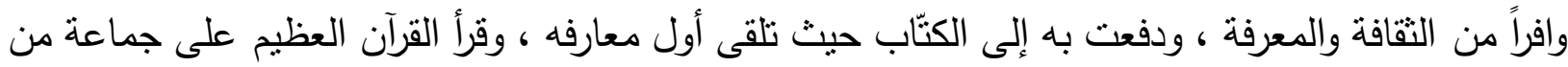

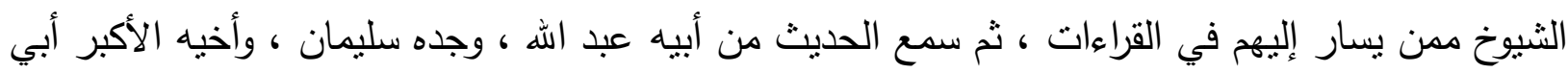

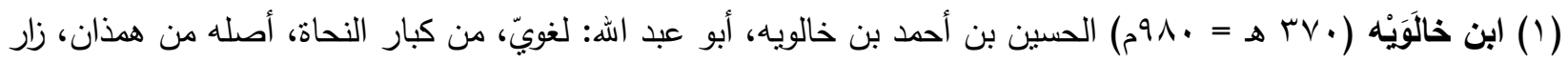

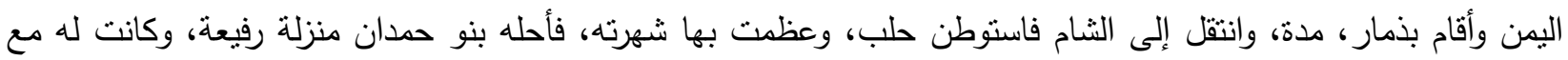

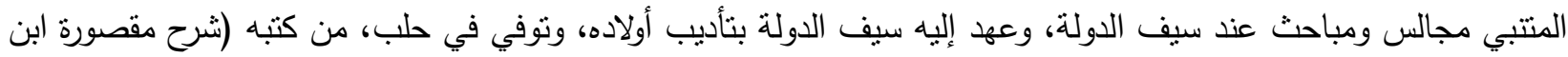
دريد)و (مختصر في شواذ القرآن) و (إعراب ثلاثثن سورة من القرآن العزيز) و (ليس في كلام العرب) و (الثجر) ويقال إنه ل لإله

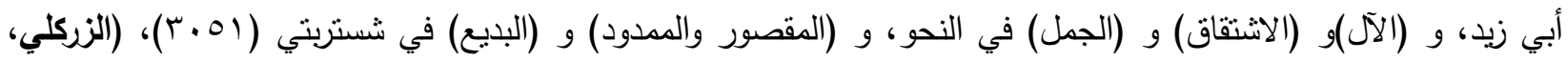

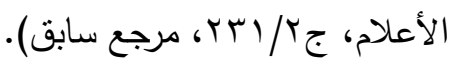

(Y) إيهاب عبد الحميد عبد الصادق سلامة، شرحا أبي العلاء والخطيب التبريزي على ديوان أبي تمام دراسة نحوية صرفية،

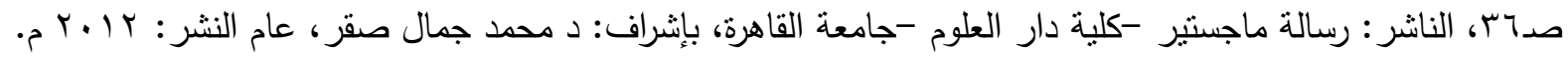




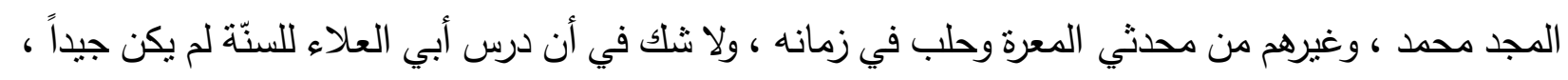

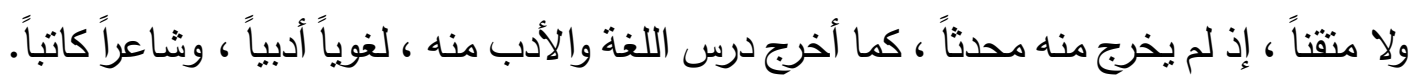

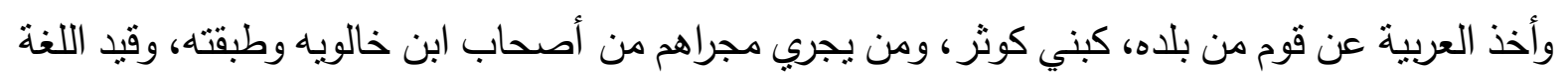

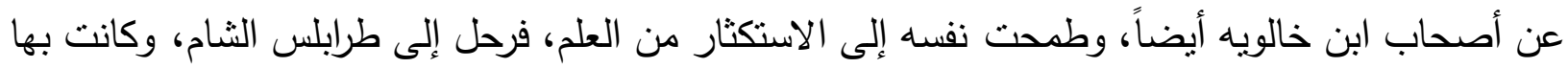

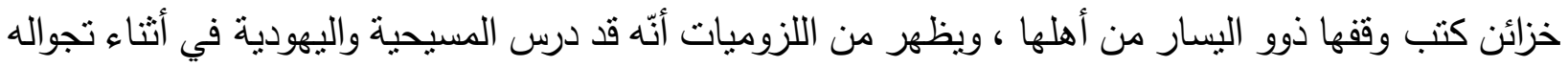

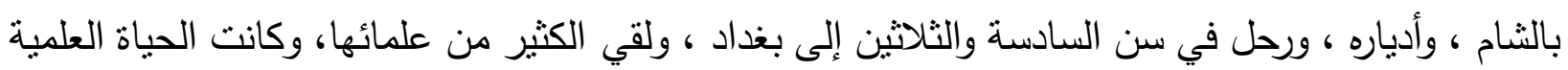

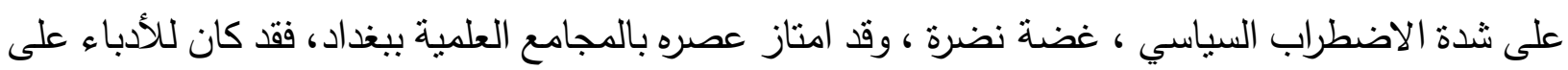

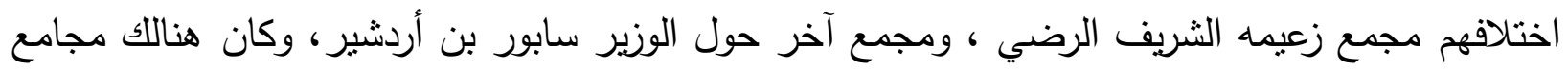

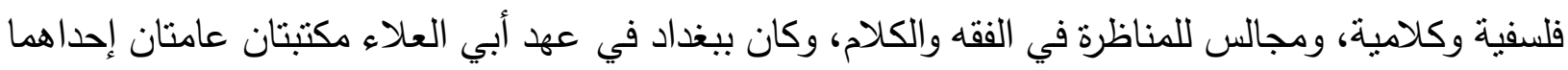

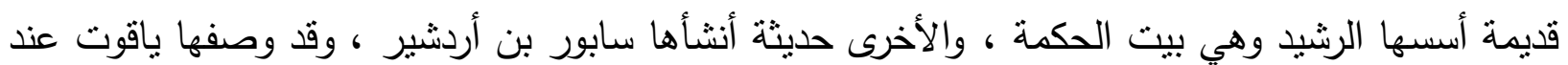

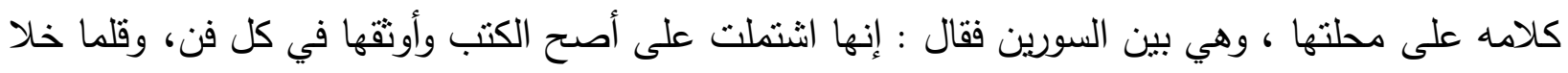

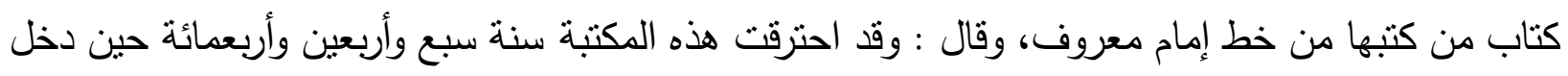

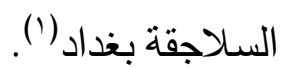

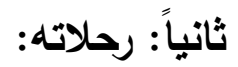

ذكر أبو الفذاء أن أبا العلاء دخل بغداد واستفاد من علمائها ولم ينلمذ لأحد أصلا، وهو يخالف ما ذكره

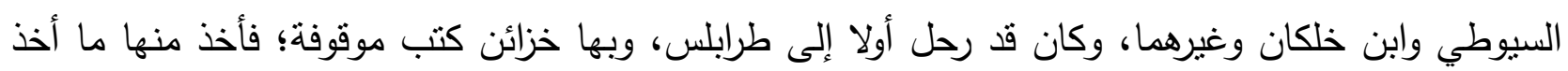

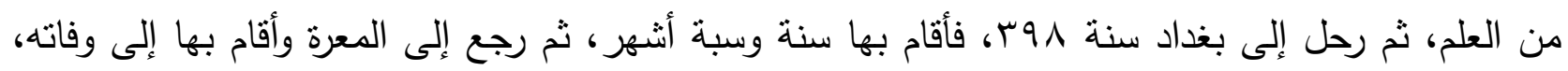

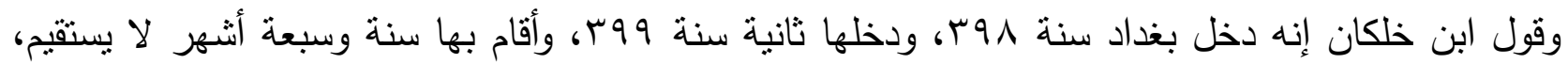
(وذلك من خلال مؤلفاته وتصريحات أبي العلاء بنفسه)، ومن تصريحه عن نفسه أن رجوعه إلى المعرة

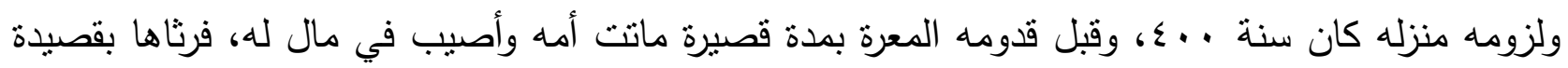

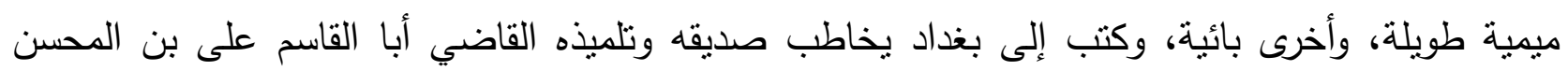

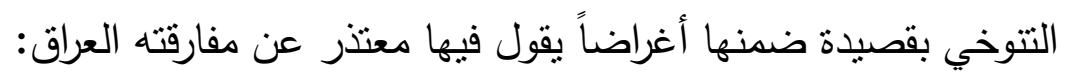

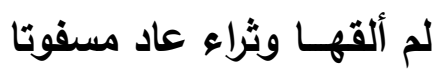
قبل الإياب إلى الأخرين أن موتاء ماءنا عنسي دليـلا كسر الغمد إصليتا أرثاني عنكم أمران والـدة

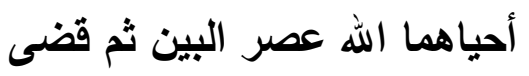

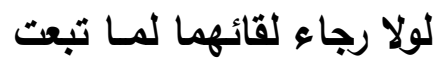

(1) أحمد يحيى علي محمد، الدصطلحات البلاغية في شرح أبي العلاء لشعر المتنبي، أطروحة علمية قدمت لمجلس كلية

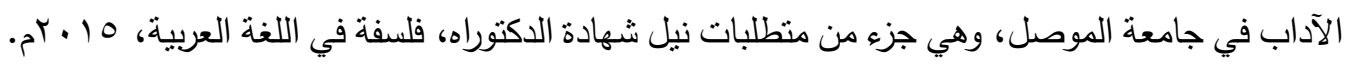


تراقب الجدي في الخضراء مسبوتا (1)

ولا صحبت ذنئاب الإنس طاوية

يقول ابن العديم: رحل إلى بغداد لطلب العلم والاستكثار منه، والاطلاع على الكتب ببغداد ولم برحل لطلب دنيا ولا رفد، وقد ذكر في قصيدته التي قرأتها على شيخنا أبي الحسن بن عمرو الموصلي بحلب قال: أنثدنا

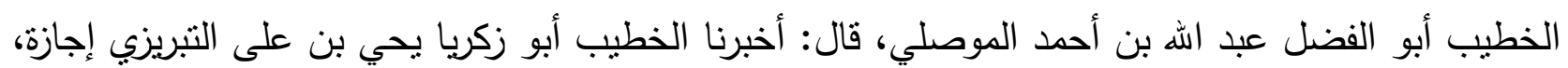
قال: أنشدنا أبو العلاء أحمد بن عبد الله بن سليمان لنفسه وكتبها من بغداد إلى أهله، بريد بالمعرة:
يا لله الأخبرتكم بمحال

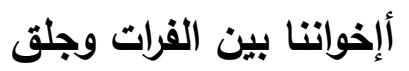
ووجهي لما يبتذل بسؤال
أنبئكم أني على العهد سالم
تيممه غيلان عند بلال (r)

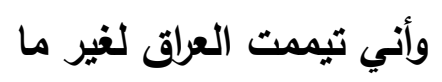

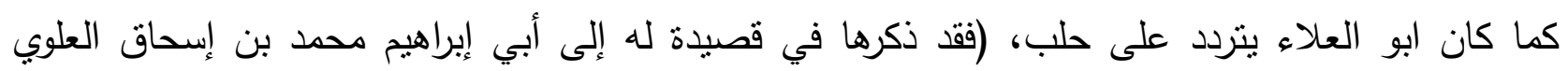

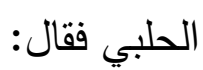

والسير عن حلب إليك رحيل

فتسأل ربي أن يخفف من إثمي
ليت التحمل عن ذرالك حلول

وهو الذي رثاه وقد مات بحلب بقصيدة آخرها:

ولعله كان يتردد إليه بحلب إذ أقام بها عند أخواله وكان أبو إبراهيم ضرب من قرض الشعر بنصيب فأنفذ إليه نونية أجاب عنها صاحبنا بمتلها (r). أما رحلاته إلى أنطاكية واللاذقية وطرابلس وصنعاء وغيرها من هذه البلدان فعلي الأصح أنها لم تثبت.

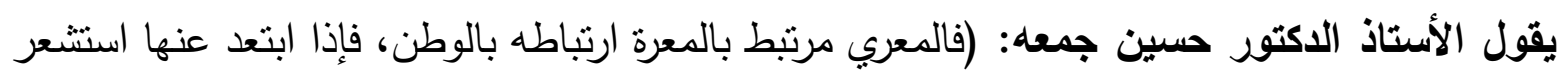

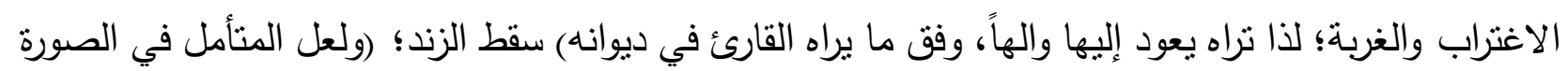

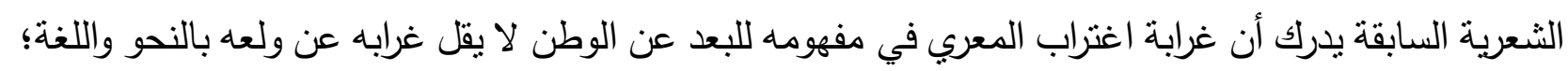
ومضاهاة افتراقه للمعرة بمضاهاة فراق حرف) الواو (لفعل) وعد (حين يصاب بالإعلال ....وإذا كان الإعلاد

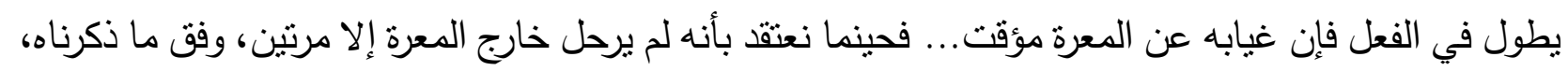

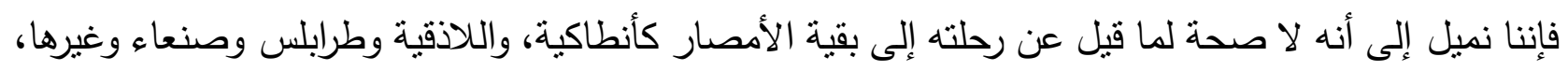

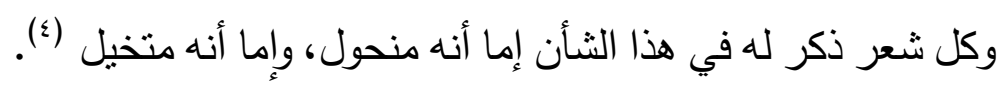

(1) (1) أحمد تيمور باشا، أبو العلاء المعري، صد VI ا، مرجع سابق.

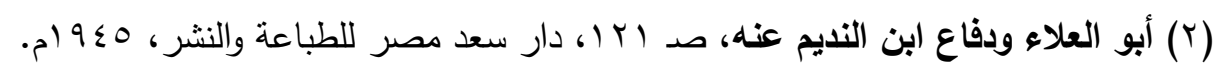

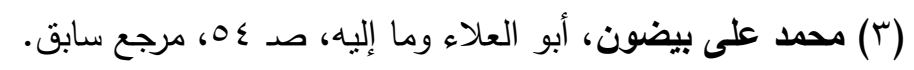

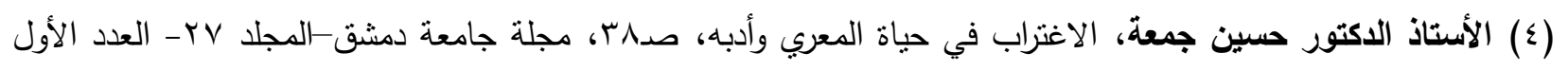




\section{ثالثاً: عزلة أبي العلاء وآثارها عليه:}

ولمّّا قدِم بغداد عزمَ على العُرْلة والانقضاب من العالم، فكتب إلى أهل المعرة:

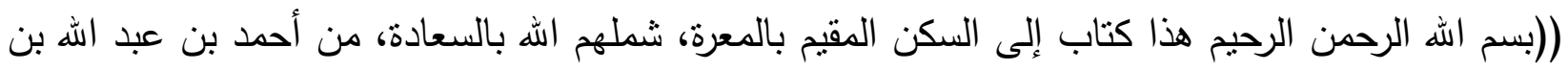

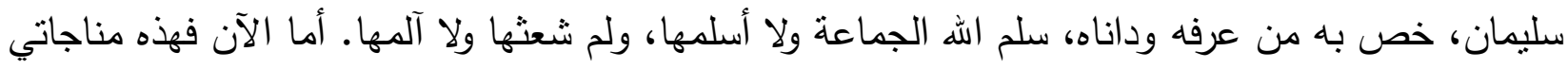

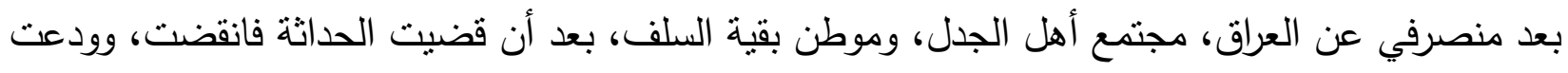
الثبيية فمضت، وحلبت الدهر أثطره، وجربت خيره وشره؛ فوجدت أقوى ما أصنعه أيام الحياة، أن اخترت

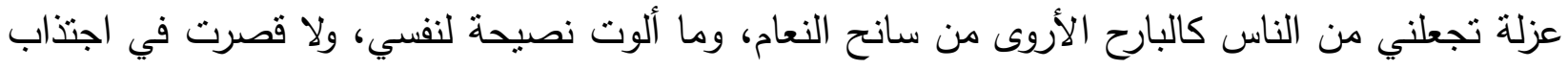
المنفعة إلى حيزي؛ فأجمعت على ذلك، واستخرت الله فيه، بعد جلائه على نفر يوثق بحصائلهم؛ فكلهم رآه

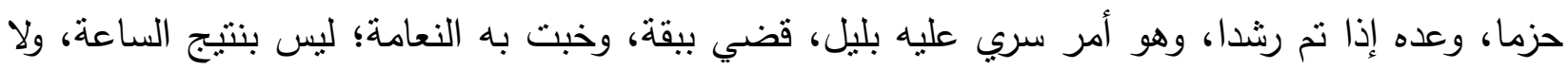

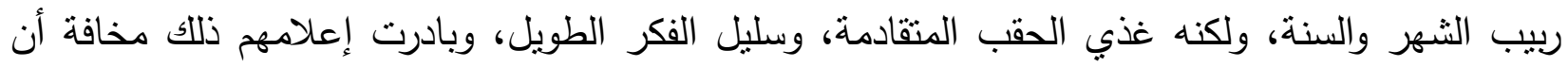

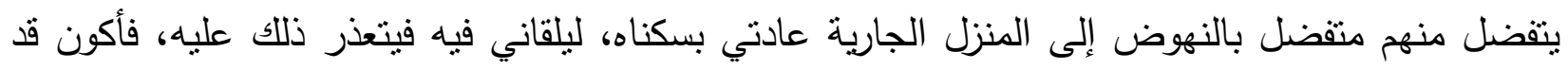
جمعت بين سمجين: سوء الأدب، وسوء القطيعة، ورب ملوم لا ذنب له، والمتل السائر : "خل امرأ وما اختار ".

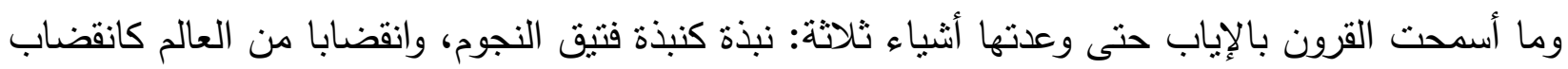

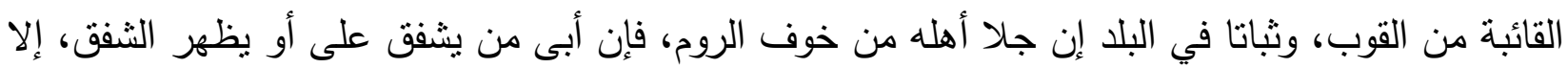

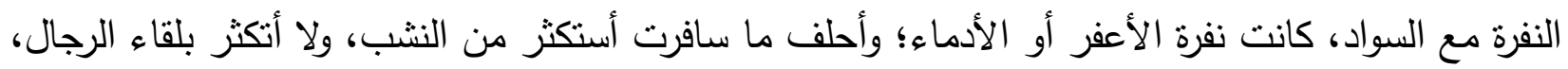
ولكن آثرت الإقامة بدار العلم، فنشاهدت أنفس ما كان لم يسعف الزمن بإقامتي فيه. والجاهل مغالب القدر.

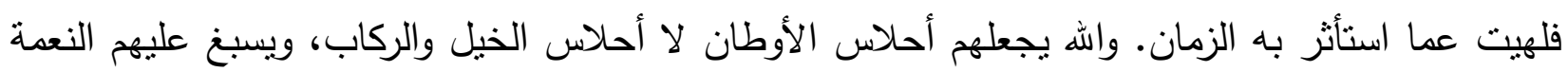

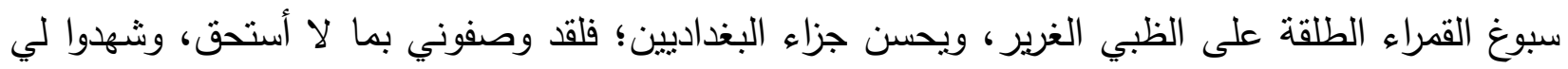

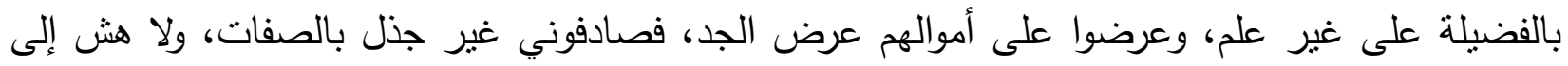

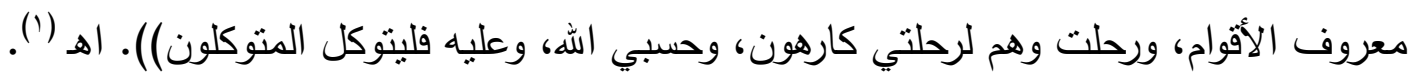

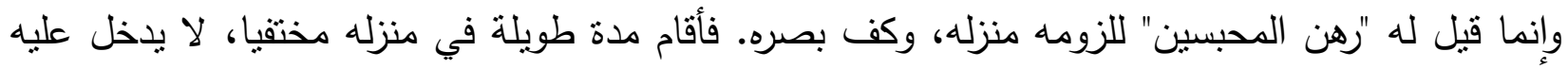

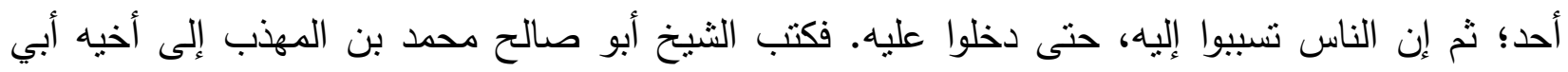
الهيثم عبد الواحد بن عبد اله بن سليمان -رحمهما الله-في ذلك:

(1) عمر بن أحمد بن هبة الله بن أبي جرادة العقيلي، كمال الدين ابن العديم (.77 هـ)، الإنصاف والتحري في دفع الظلل

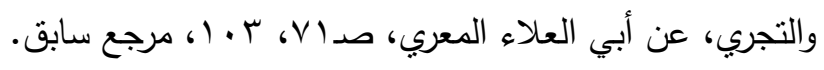


ألما وإن كان الجميع شجاني

ولو رضيت هجرانها لكفاني

ولو علمت أن الرقاد جفاني

بها تحت أرواق الاجى ويراني

فكم من خليل زارني فثفاني (')
بشمس زرود لا ببدر مـعان

أراها أبت إلا النوى بي مغرمـا

تمن بإهداء السـلام تجـاهلا

هبي هجعة كيما أرى الطيف مرة

لعلي أثثفي علتي بلقـائهد

وهذا أبو صالح قائل هذا الثعر، هو أبو صالح محمد بن المهذب بن علي بن المهذب بن أبي حامد بن

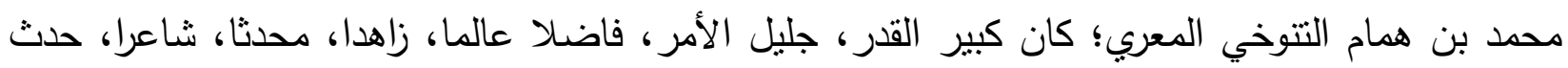
بالكثير عن أبي العلاء المعري، وجده علي بن المهذب بن محمد، والقاضي أبي عمرو عثمان بن عبد الله بن

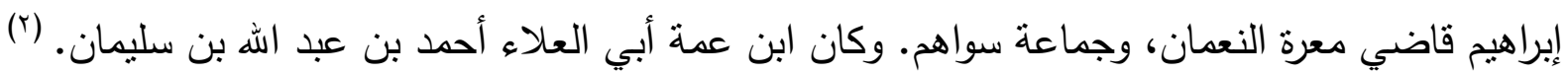
رابعاً: دينه:

إن شخصية أبي العلاء المعري لهي من تلك الثخصيات العبقرية الكبرى المتعددة المزايا والصفات التي يصعب على الباحثين وأن لم يستحل أن يدركوها إدراكا كليا وأن يحددوها تحديدا شاملا.

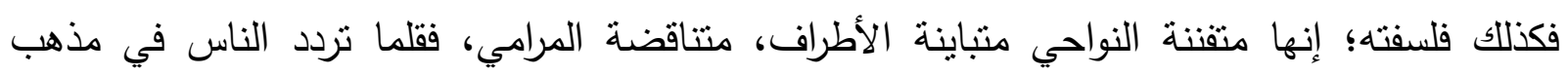
كترددهم فيها، وقلما اختلف العلماء على تتوع طبقاتهم في غابر الزمان وفي حاضره كاختلافهم فيه.

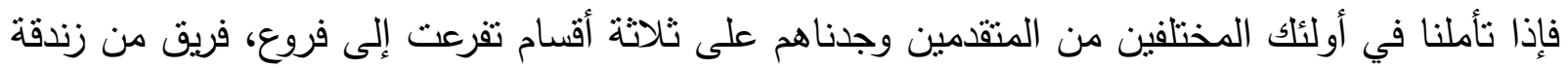

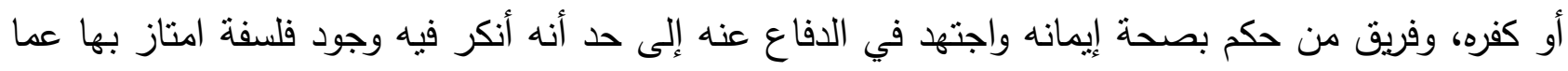

سواه وفريق تحير في شأنه وما جرأ على شتمه ولا على تبريره فأمسكوا عنه وفوضوا أمره إلى خالقه (r). كما يتهم الكثيرون أبا العلاء بجدد النبوات، وعدم الإيمان بالبعث والنشور ، وكثيرا ما يتعدون تحريف وهيف كلمه، أو صرف ظاهره إلى غير مراده، افتيانا عليه، وانتصارا لمدعاهم، فضلا عما وضعوه على لسانه من الكذب والبهتان كما أثنته نقلة أخباره (£).

( (1) (للأبيات بقية لا يتسع المجال لذكرها. (Y) عمر بن أحمد بن هبة الله بن أبي جرادة العقيلي، كمال الدين ابن العديم (·rآ هـ)، الإنصاف والتحري في دفع الظلم

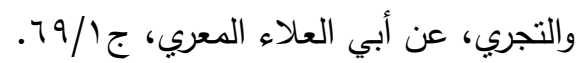

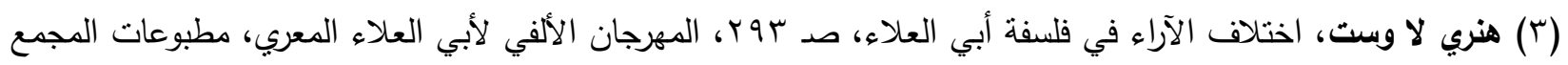

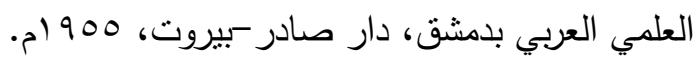

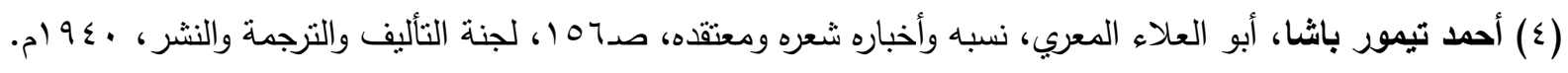


هل حقا عارض أو العلاء القران الكريم؟

لو حكمنا عقلنا في هذه المسألة نقول (كيف يقدم أبو العلاء على ما لم يحاول أن يقدم عليه العرب

جميعاً، وهم في مواجهة الدعوة الإسلامية؟ وفي مقام تحدي القران لهم أن يأنوا بسورة من مثله؟.

إن الذي حال بين ابي العلاء وبين أن يلقي بنفسه في محيط هذا البحر المحيط العميق هو الذي حال هال ويحول بين كل ذي عقل، وبين هذا الموقف الذي تقتحمه في الأبصار، وتزدريه العقول، وتتزله منزلة البله

والمجانين.

فهل مثل أبي العلاء، وهذا حظه من العقل ومبلغه من العلم وحاله من المعرفة بمواقع البلاغة والبيان بالذي تسول له نفسه أن يهتز ، ويهذي في موقف الجد فيصبح أضحوكة الزمن، وسخرية الأجيال؟ ونا؟

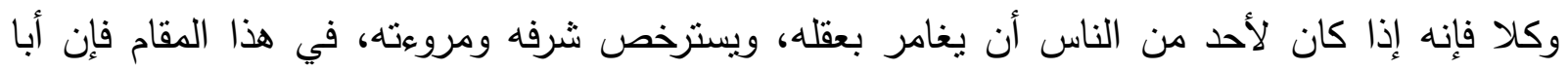

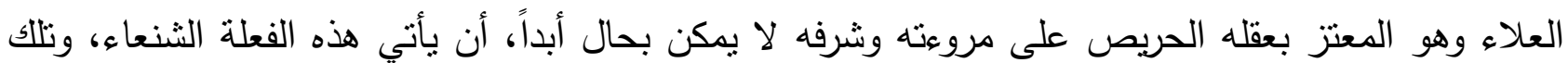

الفضيحة المخزية أبد الدهر) (').

وإليك أخي القارئ الاليل القاطع على عكس القول باعتراض أبا العلاء على أحكام القران: من قال بمثل هذا القول استنل بكتاب أبا العلاء المعنون بـ (الفصول والغايات في محاذاة الفصول والآيات)، الذي ألفه أبا العلاء أواخر حياته.

وعلى هذا نقول: أن الذي ينظر في هذا الكتاب دون أن يقرأ عنوانه أو يتعرف على مؤلفه، يرى أنه كتاب

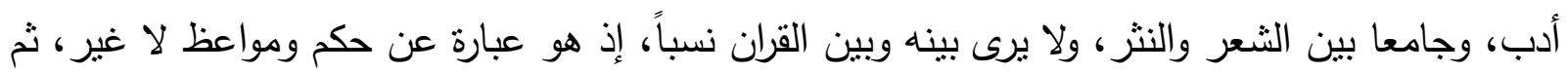

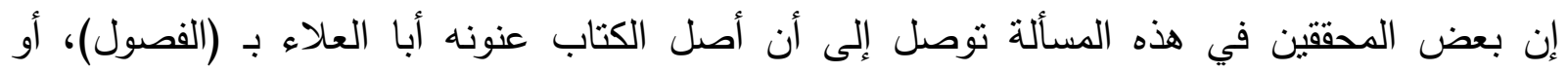
الفصول والغايات.

وقد كانت هذه الكلمة المضافة كذبا إلى عنوان الكتاب وهي (ومحاذاة السور والآيات) اتهاما مسبقا لأبي العلاء بمعارضة القران، دون أن ينظر المتهمون له إلى ما جاء في الكتاب من مقولات، حتى يحكم عليه

بما قال (؟).

وبعدما قامت الباحثة بمراجعة كتابات من تكلموا في عقيدة أبا العلاء المعري ووجدت اختلافات جوهرية

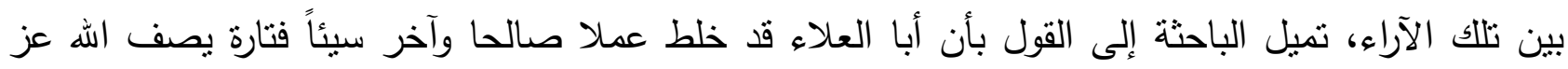

(1) عبد الكريم الخطيب، رهين المحبسين، أبو العلاء المعري بين الإيمان والإلحاد، صـ VIا، دار اللواء للنشر والتوزيع،

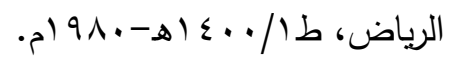
(r) ينظر : المصدر السابق، صدVا Iال، وما بعدها. 
وجل بالظلم والتعارض في أحكامه (حانشاه) وتارة يثبت لله عز وجل صفاته وقدرته وأنه المعبود الواحد الأحد،

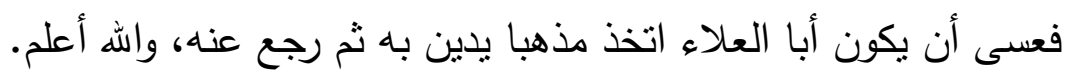

آثاره:

فأول ما ألف بعد انقطاعه في منزله، بعد رجوعه من بغداد، الكتاب المعروف بـ "الفصول والغايات" في تمجيد

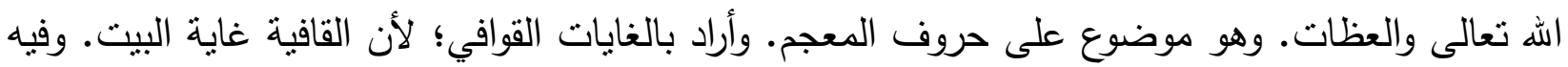

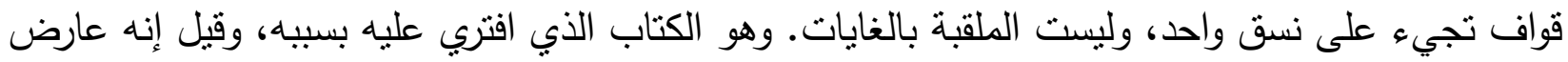

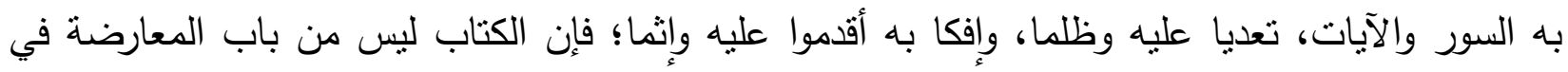
شيء. ومقاره مائة كراسة، وفيما يلي أهم أعمال أبي العلاء المعري: واعيا 1 - كتاب "السادن" وضعه في ذكر غريب هذا الكتاب وما فيه من اللغة. ومقداره عشرون كراسة. r - - كتاب "إقليد الغايات"، وهو مشتمل على تقسير اللغز • ومقداره عشر كراريس. "ا- ثم ألف الكتاب المعروف بال "الأيك والغصون"، وهو كتاب كبير ، ويعرف بكتاب "الهمز والردف"، بني

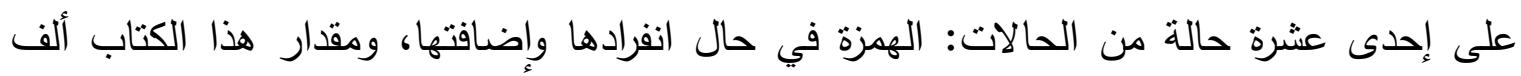
ومائتا كراسة. وهذا الكتاب قليل الوجود لكبره، ولم أقف إلا على جزء واحد منه، وبعضه موقوف في خزانة كتب النظامية ببغداد. وبالديار المصرية منه نسخة كانت في خزائن المصريين، صارت إلى وره القاضي الفاضل عبد الرحيم بن علي البيساني، وانتقلت إلى ولده القاضي الأشرف. لئه ع - "كتاب في تفسير الهمزة والردف" جزء واحد. 0- والكتاب المعروف بـ "تضمين الآي"، يتضمن العظات، والحث على تقوى الله تعالى. 7- والكتاب المعروف بـ "تاج الحرة" وهو في عظات النساء خاصة. -V - V والكتاب المعروف بـ "سيف الخطبة"، يشتمل على خطبة السنة، فيه خطب الجمع، والعيدين، والخسوف، والكسوف، والاستشقاء، وعقد النكاح. 1- - كتاب " خطب لختم القرآن العزيز"، فيه عدة خطب لذللك، مقداره خمس كراريس. 9- والكتاب المعروف بـ "خطب الخيل"، يتكلم فيها على ألسنة الخيل، ويذكر على لسان كل فرس خطبة يحمد الله تعالى فيها ويعظمه. • ( - والكتاب المعروف بـ "خطبة الفصيح". يذكر فيها الألفاظ التي تروى عن ثعلب في كتاب الفصيح، في ضمن كلام فصيح منثور، في كل باب من أبواب الفصيح. ومقداره خمس عشرة كراسة. | (ا - وكتاب شرح فيه ما جاء في هذا الكتاب من الغريب يعرف بـ "تفسير خطبة الفصيح"، لا أعلم مقداره، ولم أقف عليه. 
r ا ا - وكتاب يعرف بـ "رسيل الراموز"، مقداره ثلاثون كراسة.

س ا - ومن الكتب الصغار كتاب يعرف بـ "خماسية الراح"، في ذم الخمر خاصة، على حروف المعجم. ع ا - وكتاب يعرف بـ "المواعظ الست" سأله فيه بعض الوعاظ. ومعنى هذا اللقب أن الفصل الأول منه في

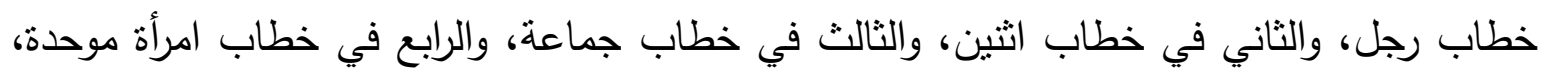
والخامس في خطاب امرأنين، والسادس في خطاب نسوة. ومقداره خمس عشرة كراسة.

0 7 ا 1 - وكتاب يعرف بـ "دعاء الساعة". وهما مختصران، ولا أعلم مقدار حجمهما. ا IV 1 ا - وكتاب "حرز الخيل"، لا أعلم مقداره. و"جزء فيه حرز وتعويذ" لا أعلم مقداره.

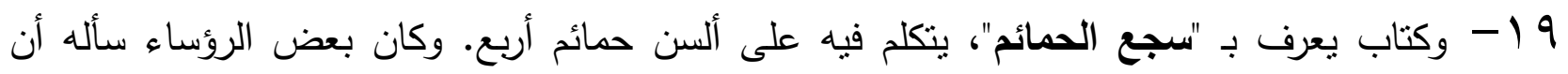
يصنف له تصنيفا يذكره فيه، فأنشأ هذا الكتاب، وجعل ما يقوله على لسان الحمامة في العظة والحث

$$
\text { على الزهد. ومقداره ثلاثتون كراسة. }
$$

• Y - وكتاب يعرف بـ "تظلم السور"، يتكلم فيه على لسان سور القرآن، وتتظلم كل سورة ممن قرأها بالثواذ، ويتعرض لوجه الثناذ. مقداره ست كراريس.

ا Y- وكتاب يعرف بـ "عظات السور" يشتمل على مواعظ. لا أعلم مقداره. r Y - وكتاب يعرف بـ "الجلي والجلي". سأله فيه رجل من أكابر الحلبيين يقال له أبو الفتح عبد الله بن

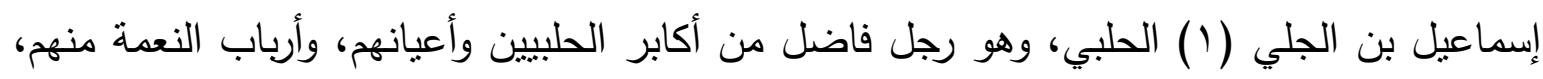

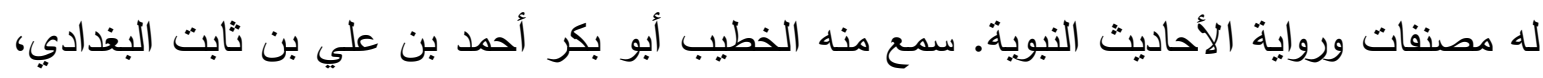

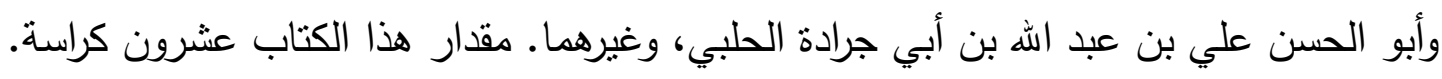

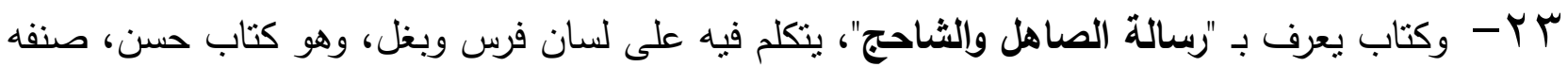

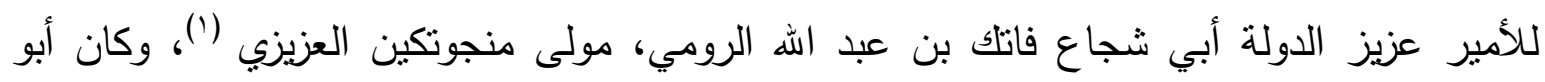

( (العزيزي أمير دمثق ينجوتكين التركي: العزيزي مولى العزيز ولي إمرة دمثق سنة إحدى وثمانين وثلاث مائة وتوفي سنة

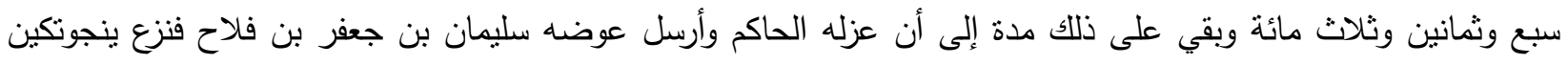

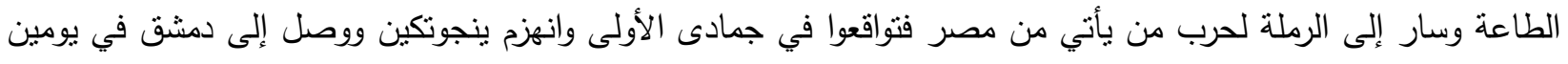

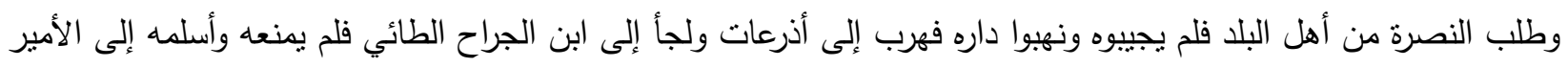

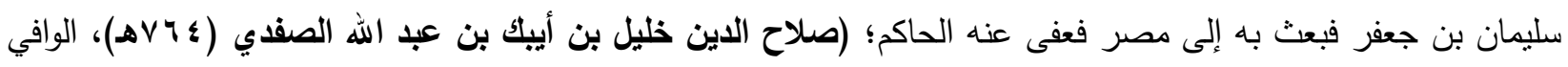


شجاع هذا والي حلب من قبل المصريين في أيام الحاكم وبعض أيام الظاهر، وكان سبب تصنيفه أنه رفع إلى فاتلك أن حقا يجب له على بعض أقرباء أبي العلاء، وجب على أبي العلاء سؤاله فيه مقداره أربعون كراسة.

ع ץ- وكتاب لطيف في تفسير الصاهل والثاحج، يعرف بـ "لسان الصاهل والثاحج"، عمله أيضا لعزيز

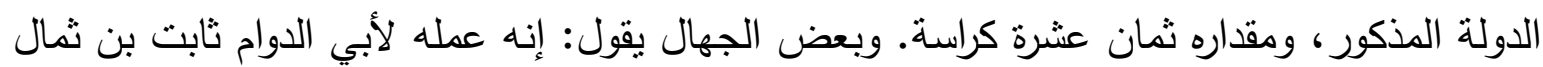

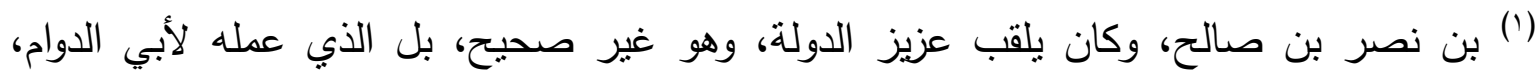

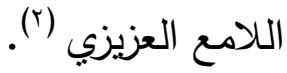
وغيرها الكثير والكثير لا يتسع المجال لذكرها...

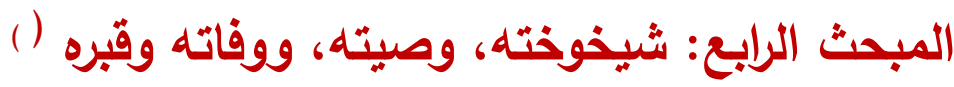

لزم أبو العلاء منزله بعد منصرفه من سنة اربعمائة ، وسمى نفسه "رهين المحبسين " ، للزومه منزلة وذهاب عينيه

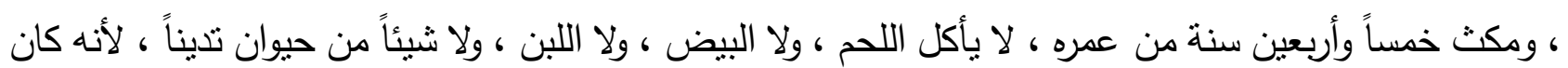

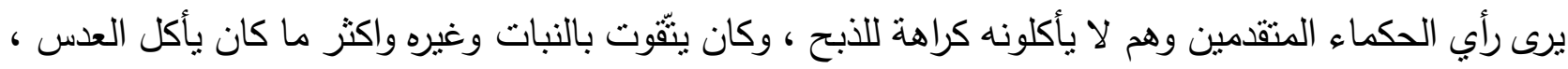

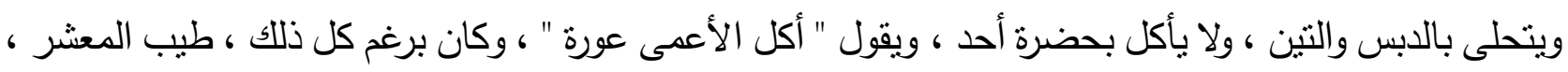

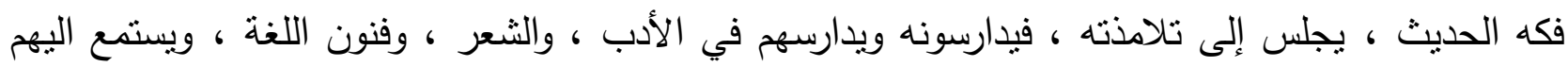
ويستمعون إليه توفّي أبو العلاء ليلة الجمعة ثاني شهر ربيع الأول ، سنة تسع وأربعين

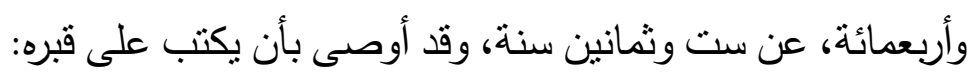

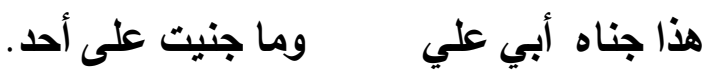

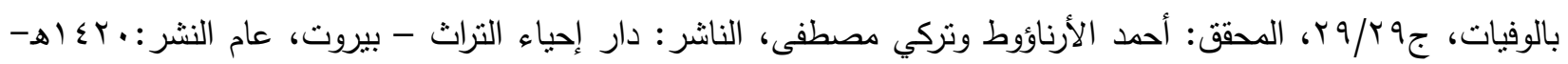
$\cdot(5, \ldots$

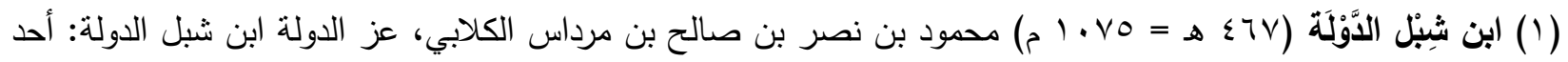
الأمراء المرداسيين أصحاب حلب. وليها سنة Oب كـ هـ ووجهت إليه حكومة مصر عمه ثمال بن صالح فانتزعها منه (سنة

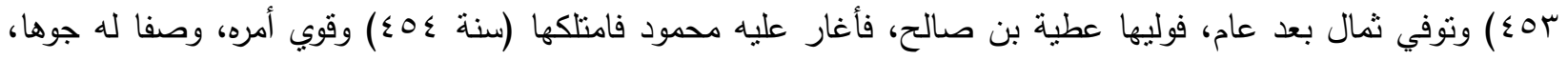
فاستمر إلى أن توفي. كان شجاعا فيه حزم؛ قال ابن العماد: كان يداري المصريين والعباسيين لتوسط داره بينهما. وقال ابن

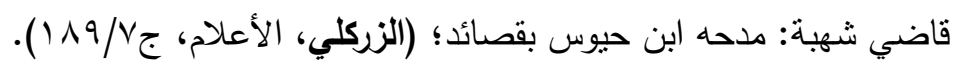

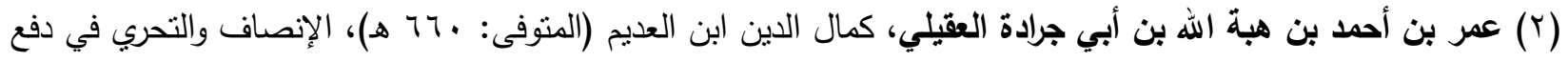

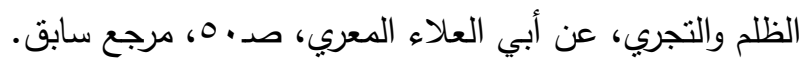


وهو أيضاً متعلق باعتقاد الحكماء، فهم يقولون :إيجاد الولد وإخراجه إلى هذا العالم جناية عليه، لأنه يتعرض

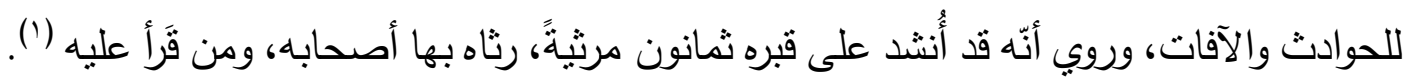

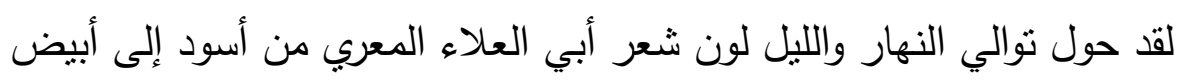

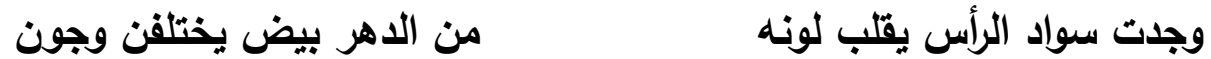

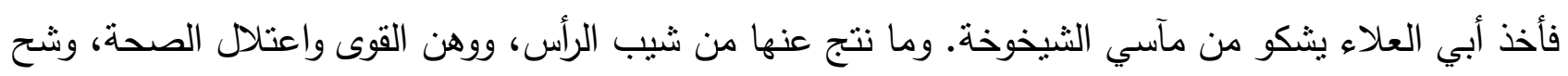

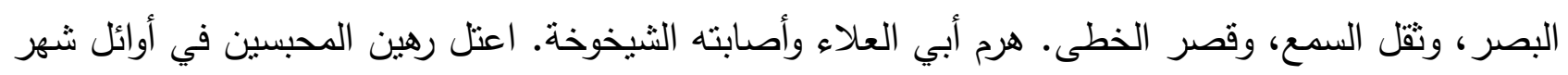
ربيع الأول من سنة 9؟ §هـ وعاده الطبيب المشهور " أبو بطلان: ابو الحسن المختار " وكان ممن يتردد عليه

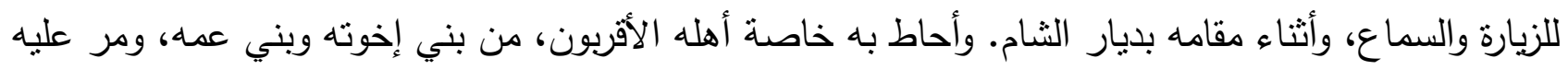

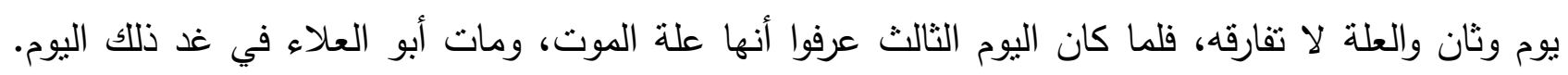
تاركاً وصيته.

ومسجلاً بها في لحظة النهاية مأساة حياته وموققه منها نوفي أبو العلاء في سنة 9؟ ؟ه بمعرة النعمان وهو في السادسة والثمانين من عمره. 


\section{الفصل الثالث: آراؤه القلسفية والتريوية ومدرسته الفكرية المبحث الأول: قثق العياة في أدب أبي العلاء المعري}

أولا: تعريف القلق وأنواعه:

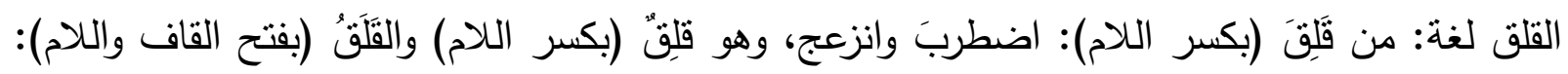

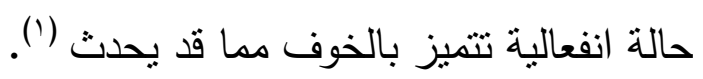

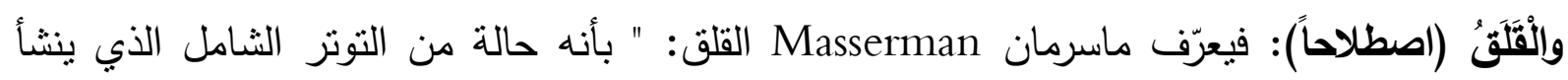

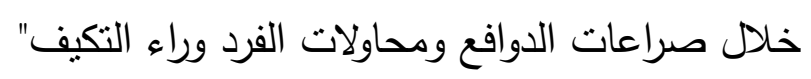

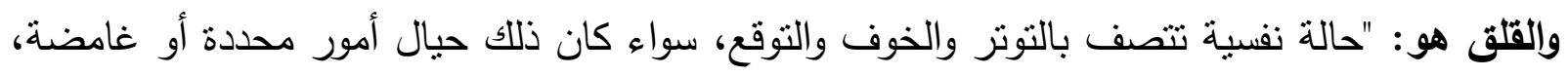

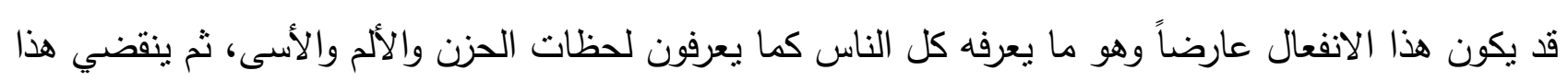
الإحساس بانقضاء أسبابه وقد يكون مزمناً ".

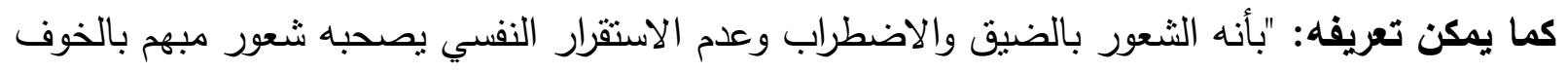

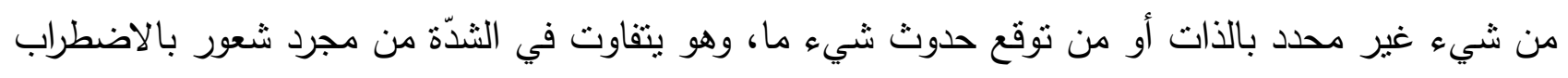

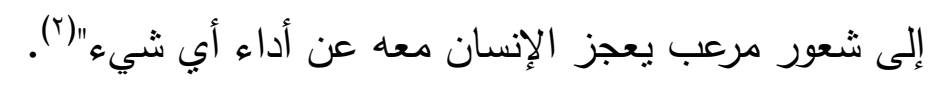

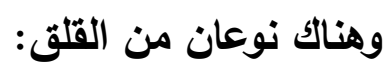

الأول: القلق المحمود حيث يكون القلق غير راض بالواقع الذي لا يروق للإنسان ولا يحقق رغباته مثل

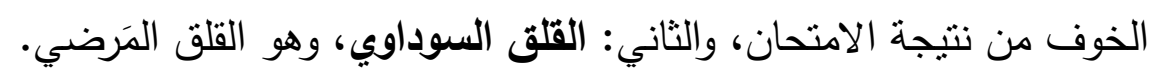
وفي هذا المبحث يقتصر على وصف ظاهرة قلق الحياة في أدب أبي العلاء المعري (مظاهرها وأسبابها)

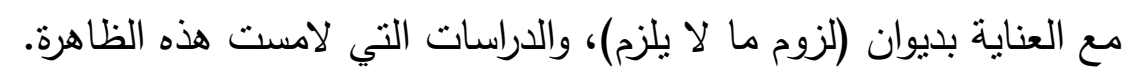

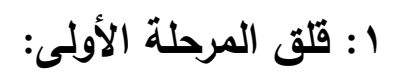

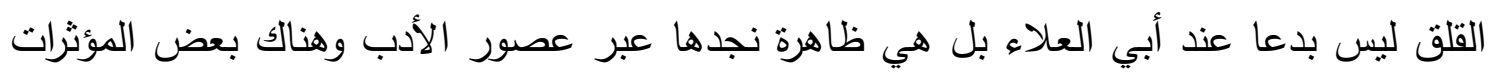

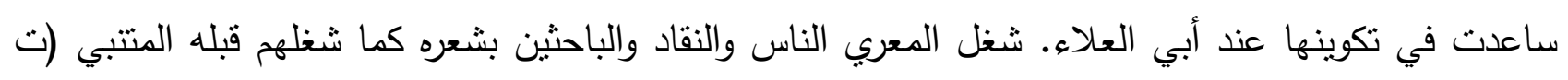
. (ATO\&

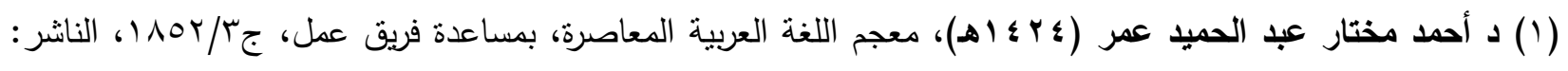

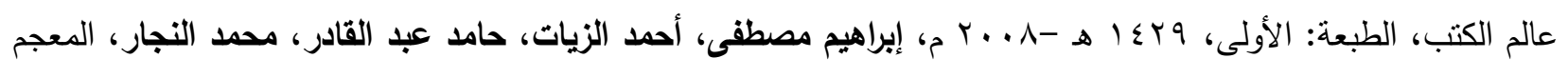

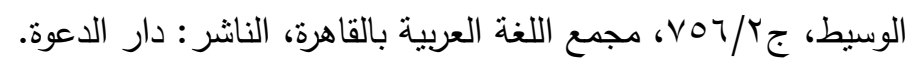

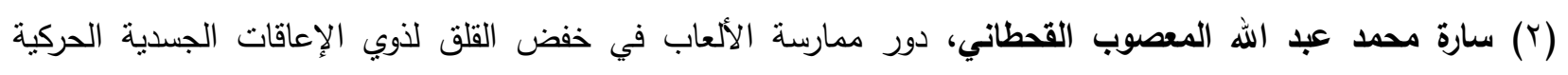

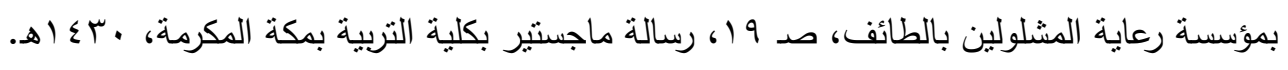




\section{r-قلث المرحلة الثانية}

لقد أقر له الكثر بأنه أعجوبة زمانه، ولكن لما لبثوا أن تحولوا عنه وقلبوا له ظهر المجن حتى وصل الأمر لإهانته في مجلس كان يضم علية القوم في بغداد، ففي مجلس الثريف المرتضى حيث يتداولون سيرة المتنبي

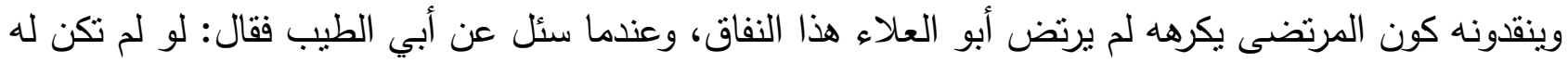

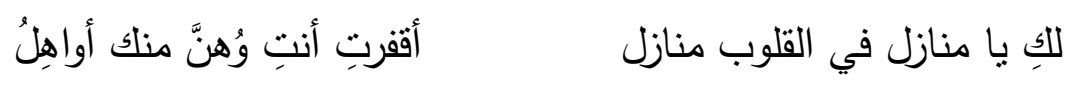
كفته فأمر الثريف بإخراجه وطرد من المجلس، وقال المرتضى إلى الحضور لم اختار الأعمى هذه

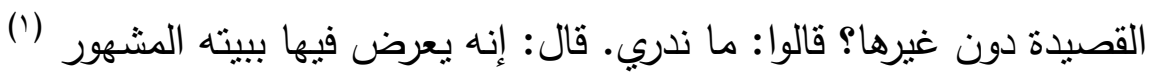

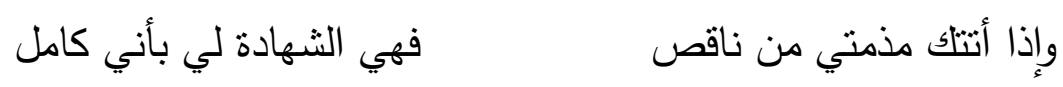
وهذه الحادثة كانت منل السهم الأصم في قلب أبي العلاء فكانت الحد الفاصل بين مجاهداته لنفساه والتعالي فوق مصييته، فقرر مغادرة بغداد والعودة إلى بيته في المعرة ليمكث خمسين سنة لا يخرج إلا إذا دفعته أمور قاهرة للخروج.

إن تجليات القلق من التأنز تبدو واضحة من خلال قراءة المعري لأسلافه من الثعراء فهو حينما يقول:

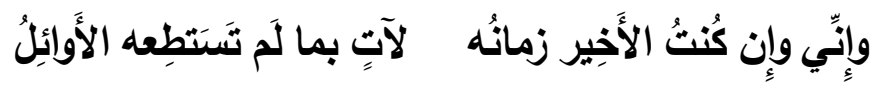

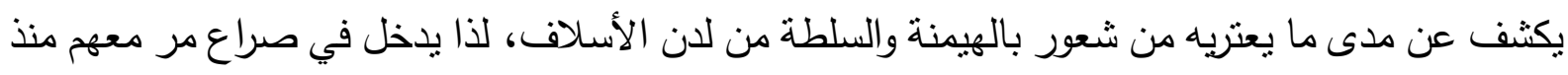

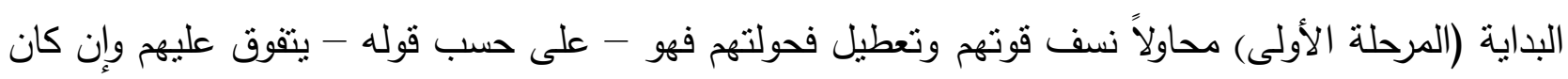

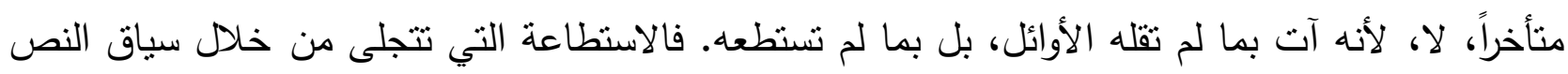

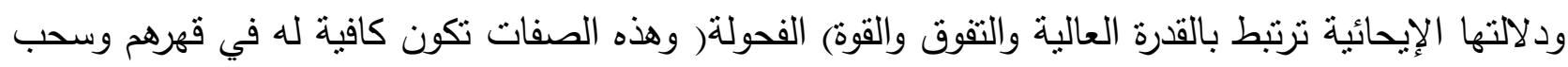

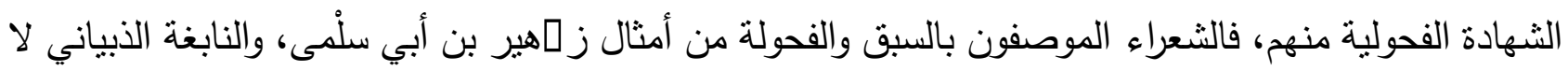

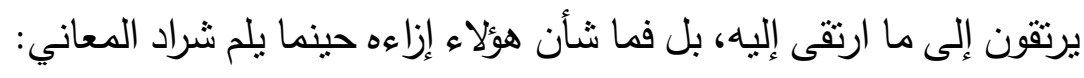

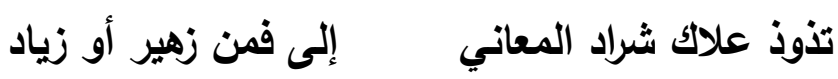
فالأسلاف برأيه - وإن كانوا سباقين إلى المعاني والصور والأخيلة غير أن ما قالوه قد مضى لئى عليه دهر وصار قديماً، إنما الفضل للجديد والجدة، إذ يقول: وإذا نضت عن متنها برد الصبا معثوقة فإلى الجفاء تؤول 
فالمشقوقة مرغوب فيها طالما كانت ترتدي برد الصبا، فإذا ما تجردت منه هجرها من كان يعشقها، وكذلك

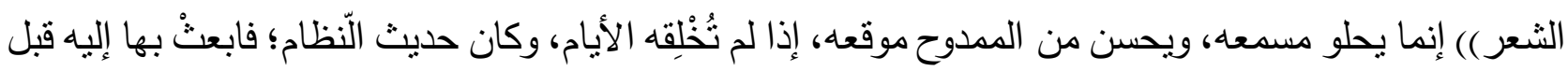

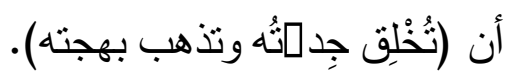

فالدعري يلجأ إلى الوسائل الدفاعية لكيلا يغدو نسخة مكررة من السلف، وان ما قاله ليس سوى إجراء دفاعي

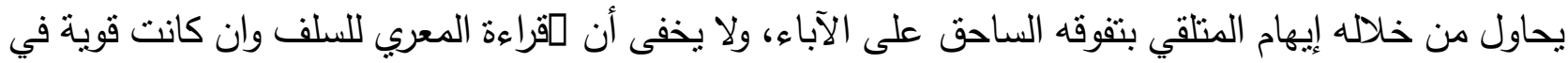

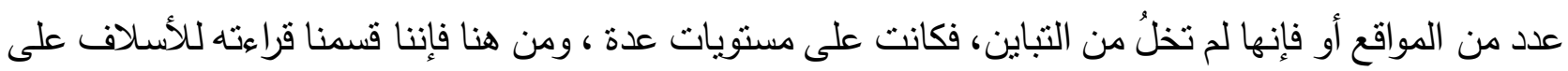

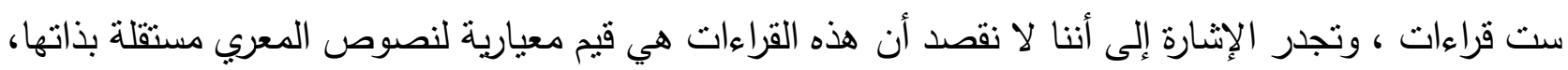
بل هي تقويم للعلاقات التي تربطها بالنصوص السابقة ومدى فاعليتها في التعامل معها وكيفية انفتاحها عليها وهذه

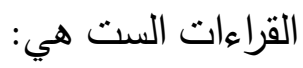
1-القراءة المحتذية :وفيها يكون الثناعر واقعاً تحت هيمنة النص السابق وسلطته.

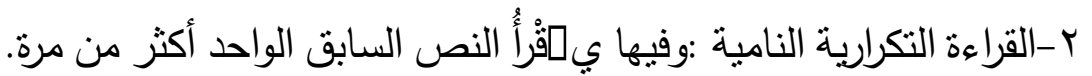
r-القراءة الموازية :وفيها يسير الثناعر في ركب أسلافه وموازياً لهم. ع -القراءة التعديلية :وهي القراءة التي تكمل النص السابق أو أو تصحصده. ه-القراءة المضادة :هي القراءة الني تقلب النص السابق وتتقضه.

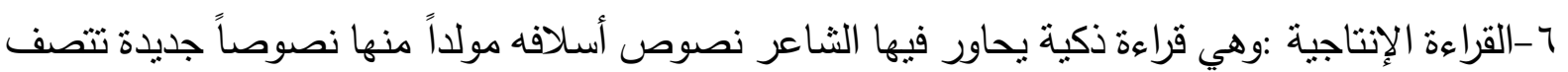
بالإبداع (') (1) (n)

\section{المبحث الثاني: الآراء القلسفية عند أبي العلاء المعري}

$$
\text { أولا: الفلسفة عند أبي العلاء: أبلاء }
$$

يقول طه حسين: إذا سمع الناس أبا العلاء لم يفهموا منه الا رجلا ملحداً، فإذا سألتهم عن علة إلحاده،

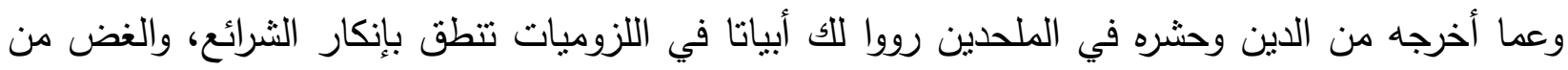

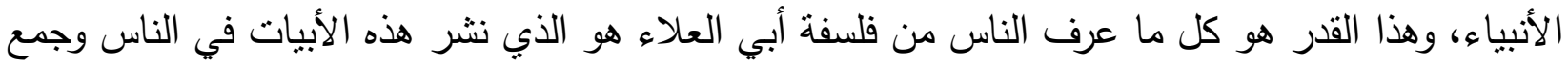

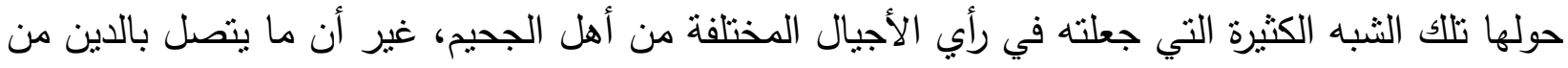

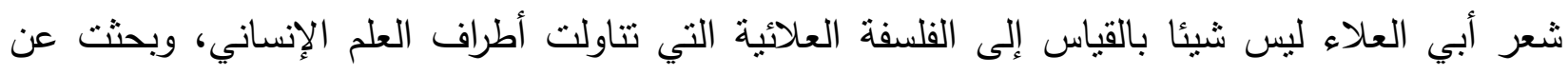

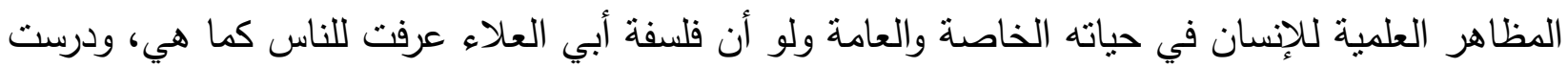
في مدارسهم درسا مفصلا، لكان للرجل في آرائهم حال غير هذه الحال، من تعصب الفقهاء عليه، وسوء رأي

(1) رمضان محمود كريم البالاني، شعر المعري من منظور القراءة والتأويل، صد م، أطروحة رسالة علمية مقدمة إلى مجلس كلية التربية جامعة بغداد. 
الدينين فيه، وتلك الحيل التي اتخذها ليخفى على الناس آراءه، وهي التي حالت بين العقول وبين فلسفته فجعلته مجهولا للتاريخ والمؤرخين على السواء من التاريخ، والمؤرخين، وإن كثر الكتاب عنه قديما وحديثا إلاهي

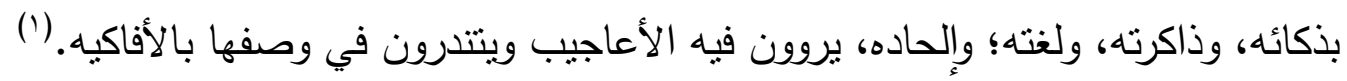
إن الثك عند أبى العلاء المعري منهج معين يسير عليه نحو الوصول إلى إلى الحقيقة، والتتاقض الظاهري لديه لا يعنى إلا مرحلة التردد بين اليقين وعدم اليقين؛ بين المنقول والمعقول، بين المتعارف عليه

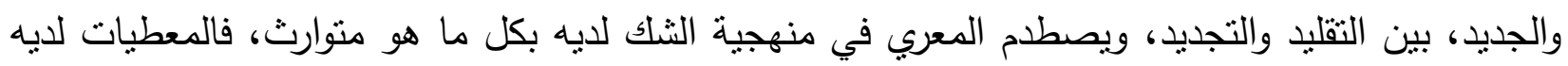
ليست مقدة والفضل -ليس كما قال القدامى -للمتقدم بل إنه يسنطيع كما قال عن نفسه:

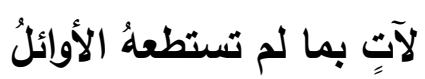
وإني وإن كنتُ الأخيرَ زمانه

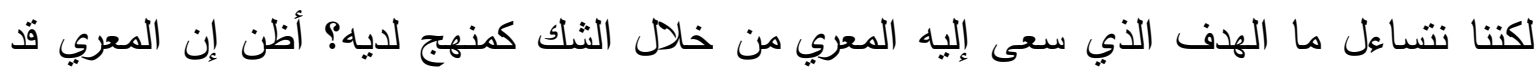

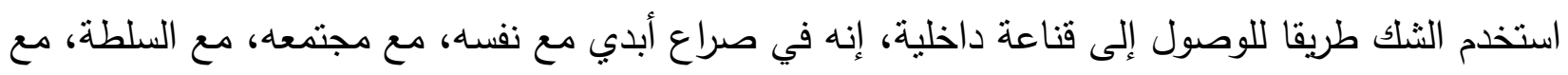

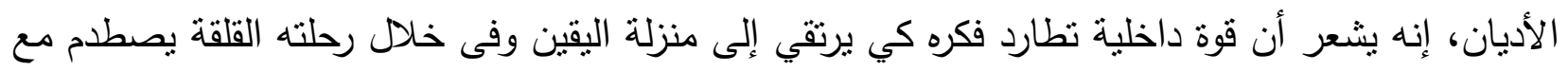
كل المؤسسات القائمة ويسعى إلى تقويمها أو تحطيمها إن لم يجد دإنى إلى تقويمها سبيلا.

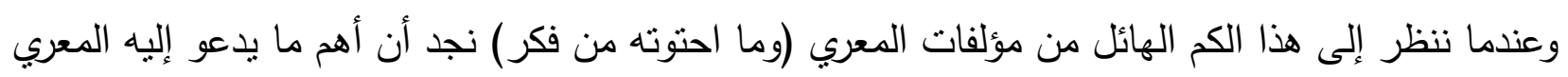

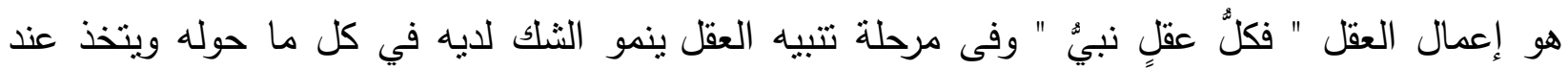

$$
\begin{aligned}
& \text { المعري ثناثة أنثكال: - } \\
& \text { (أ) الثك في الأديان. } \\
& \text { (ب) الثك في التراث الأدبي. } \\
& \text { (ج) الثك في المجتمع (r). }
\end{aligned}
$$

وحتى لا اخرج عن الإطار المحدد للبحث، سأتناول الثكل الأول فقط من أثكال الثك عند المعري (الثنك في الأديان)، في المبحث القادم ان شاء الله.

(1) طه حسين، ذكرى أبي العلاء، صدم·r، عنى بنشره وتصحيحه: توفيق الرافعي، مكتبة الهلال بالفجاله، مصر، طr/Pr 9 ام. (r) د. محمد أبو الفضل بلران، الثكك عند أبى العلاء المعري، صدو ا، جامعة الإمارات العربية المتحدة، د ت. 


\section{ثانيا: حياته القلسفية وعناصر شخصية أبي العلاء من خلال آرائه: أهم مصادر فلسفة أبي العلاء المعري:}

كان لازدهار الفلسفة، وعناية البغداديين بها أثر واضح في الدراسات النحوية، ومن ثم رأينا من النحوبين من أكثر من استعمال الأساليب الفلسفية في كلامه كأبي الحسن الرماني الذي كان يؤيد المعتزلة، وتأثز بفلسفتهر في دراساته النحوية.

وحاول بعض الباحثين المعاصرين أن ينفي وجود المدرسة البغدادية؛ معتمدا على من ينظمون أفرادها في

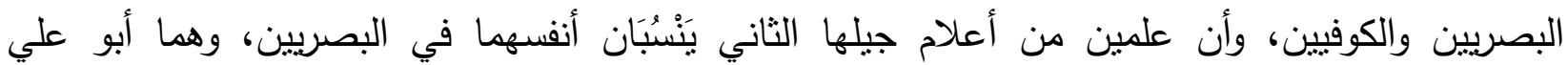
الفارسي وتلميذه ابن جني؛ إذ يعبران في تصانيفهما عنهم كثثرا بكلمة أصحابنا، وينتصران في أغلب الأمر ولهر

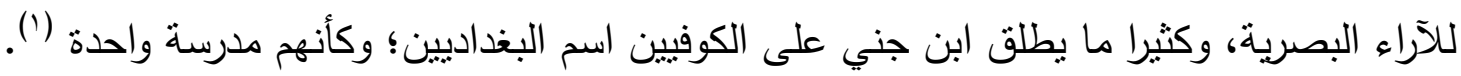

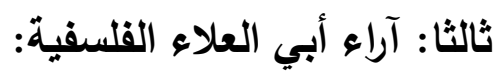
الحقيقة أن أبا العلاء نحوي لا كالنحاة، إنه أديب فيلسوف درس النحو وخبره من بعد ما حفظ اللغة ووعاها، فكان أصدق لهجة في الحكم على كلام العرب، وكره بعض تأويلات النحوبين فاحتكم إلى ما يوجبه

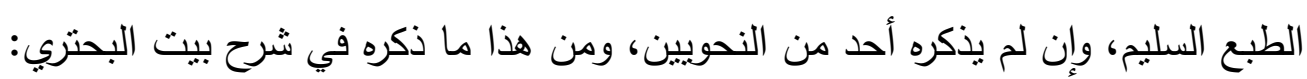

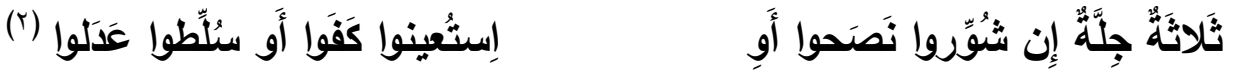

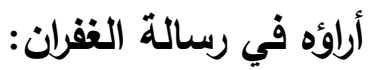

أملى أبو العلاء المعرى هذه الرسالة سنة ؟rع هـ وذللك ردا على رسالة ابن القارح، على بن منصور ،

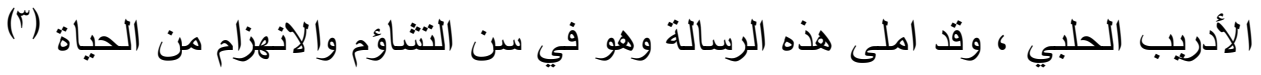

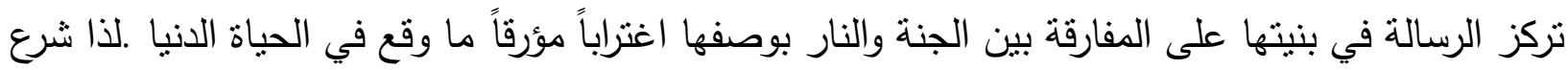

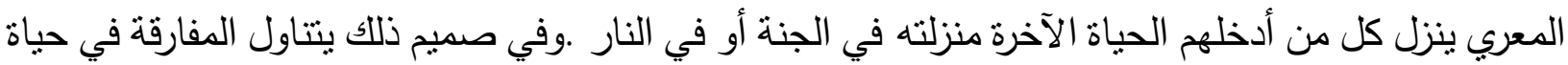

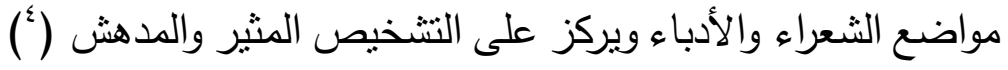

(1) إيهاب عبد الحميد عبد الصادق سلامة، شرحا أبي العلاء والخطيب التبريزي على ديوان أبي تمام دراسة نحوية صرفية،

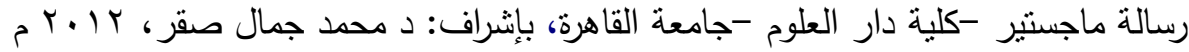
(Y) هاني محمد عبد الرازق القزلز، المسائل النحوية والصرفية في شرح أبي العلاء المعري على ديوان التران ابن أبي حصينة،

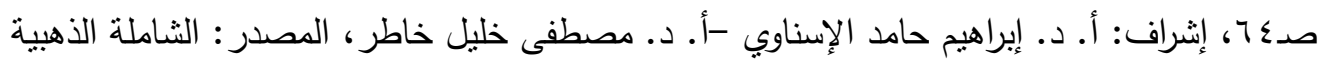

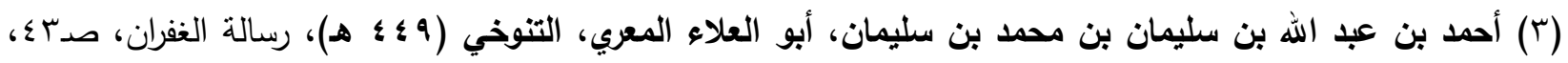

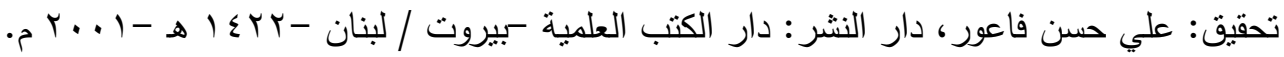

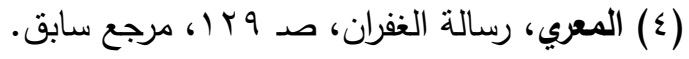


ولما كان يحقر الرجاز لفنَّه وضعهم في آخر الجنة تحقيراً لهم ... أما المفارقة في علاقته بابن القارح فهي ذات

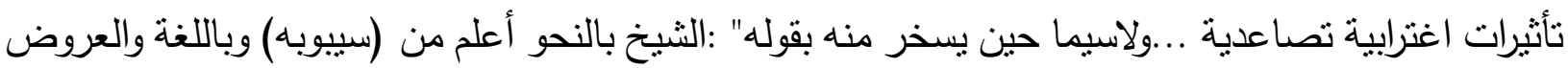

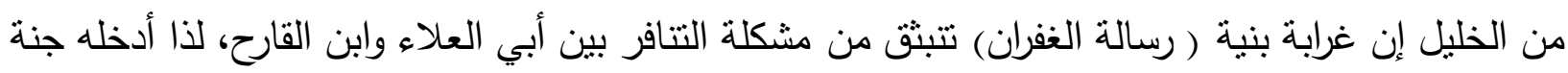

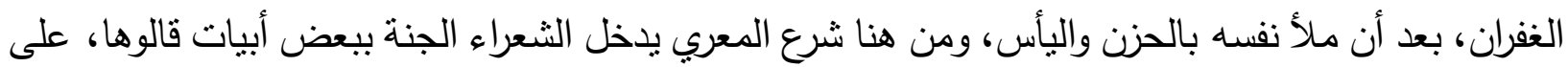

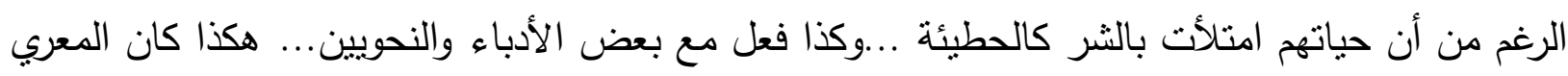

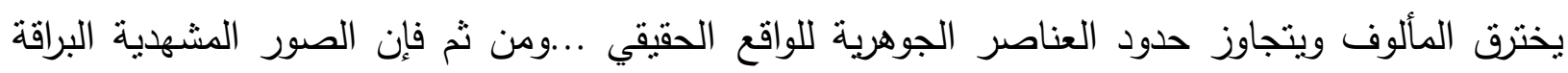
والممتلئة بالحيوية والألوان والحركة ترلد على سجوف الظلام التي عانى منها المعري، فجعل الثعراء العميان مبصرين في جنته . ولعل هذا كله يؤكد حضور عاهة العمى لديه؛ إذ كان يتحرك في عالم غيبي ولكنه مشخَّص كما لو أنه

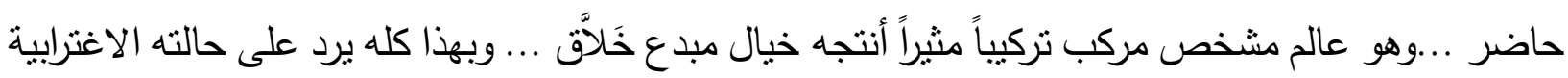

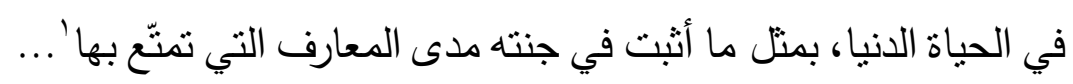

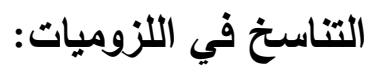
الموت والحياة:

افتزرض المعري عدداً من الافتراضات حول ماهية الموت، إذ رأى أنه نوم طويل، وفي الوقت نفسه ماتله بالنوم

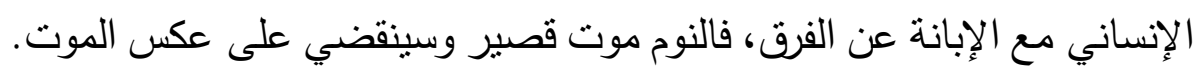
قال:

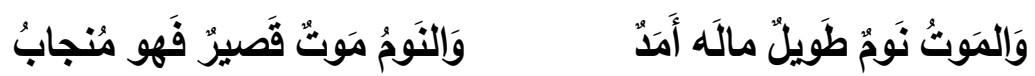

وقد أراد بقوله هذا تعميق الغياب والتلاشي بالموت، مقابل الانكثاف والبعث في النوم المؤقت، وقد تكون مقاربته تانلك من

قبيل أنهما سبيل للراحة، وأحسب أنه منأثز بالثقافة الإسلامية في هذه المقاربة.

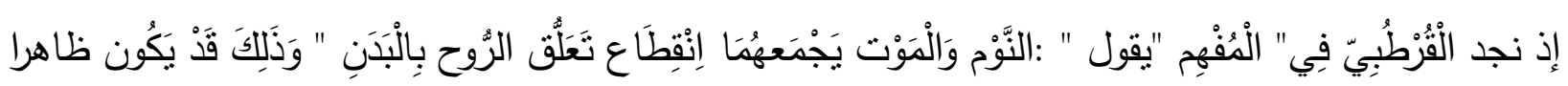

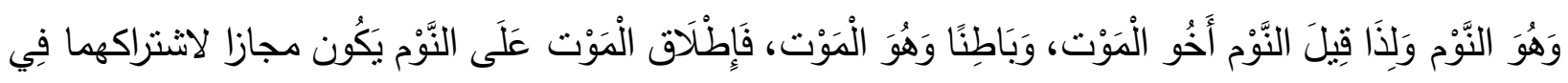

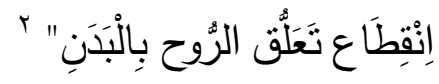

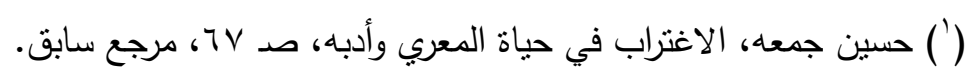

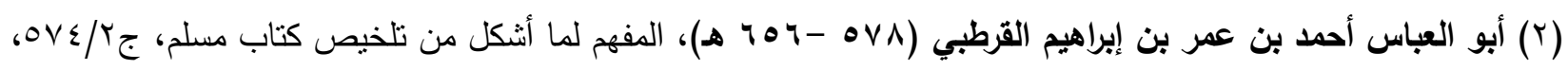

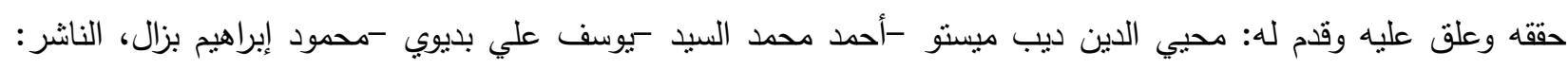

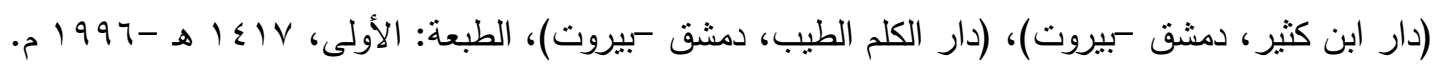


ويلفت المعري من وجهة أخرى إلى عجب الإنسان بالحياة، وما يحرزه من فضل، ويعد ذلك منه ضرباً من العبث، إذ ما القيمة التي سيجنيها من فضله لحظة مطالبة الموت به؟.

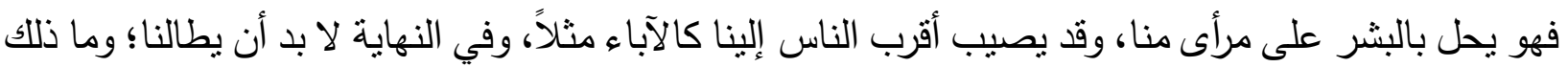
إلا لأن طبيعته تثبه الداء المعدي الذي ينتقل من إنسان لآخر . لآل

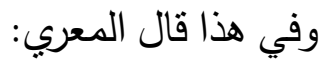

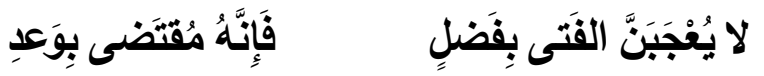

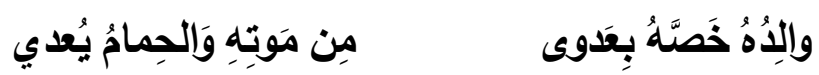

ولكن من المعروف أن ال والد هو أقرب إنسان لابنه فكيف يخصه بالموت؟ قد يكون في ذللك إثشارة إلى فضل

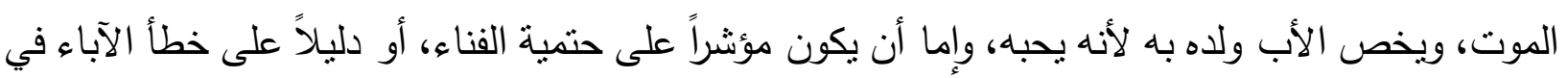

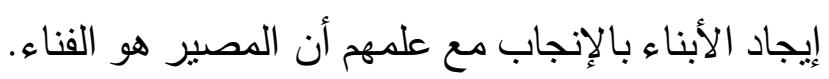

وعد المعري للموت بأنه داء نجد له جذو ارً في التراث الإسلامي، والمعروف أن الموت في الحقيقة ليس داءً،

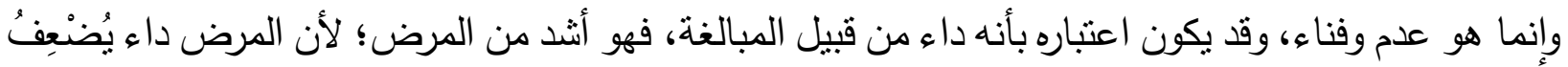

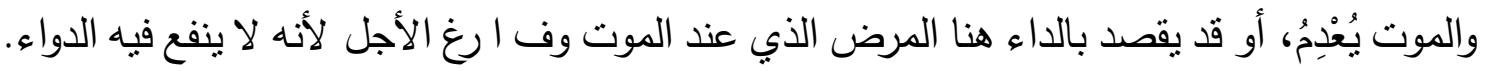

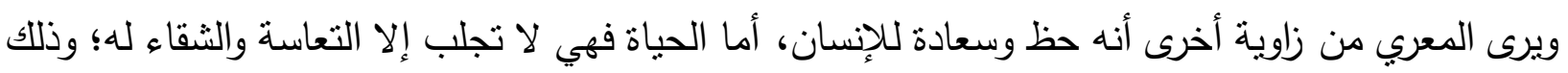

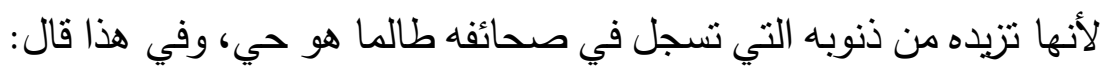

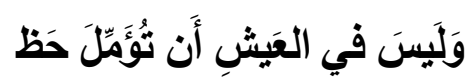

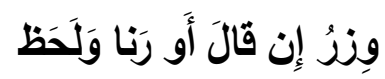

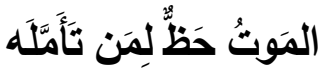

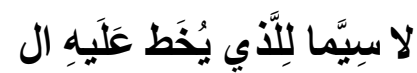

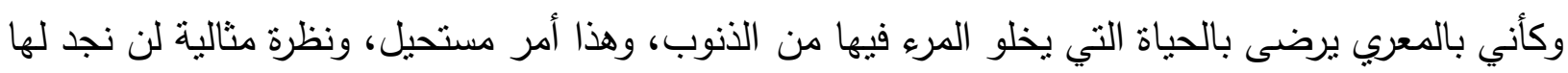

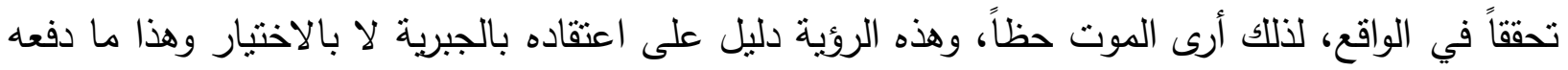

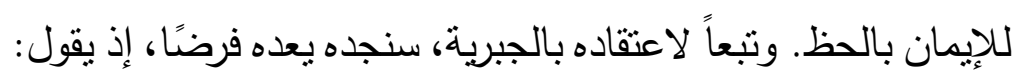

وَلَوَ أَنَّهُ بَعضُ النُجومِ الَّتَي تَسري

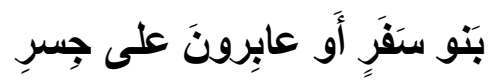

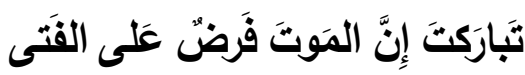

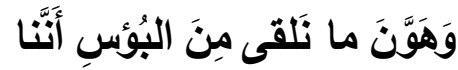

وفي وجهة أخرى يجعله غاية قريبة من نفسه، ومن نفوس ملفئ

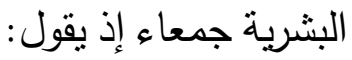

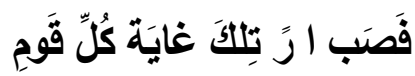

وَأَعلَمُ أَنَّ غايَتِي المَنايا

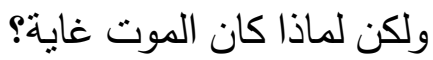




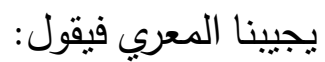

وَمَن لِي أَنْ تُخَلَّنِي وَسَومي وَمَنْ لي أَنْ يكون نَ ظِلالَ دَوِْ

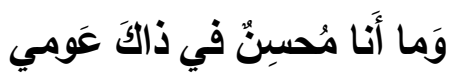

وراحتي الحِمامُ أَتَى بِنَوَمِ
وَسامَتْي إِهانَتَها اللَيَالي

وَأَيَّامُ الحَياةِ ظِلالُ عِترِ

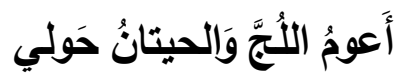

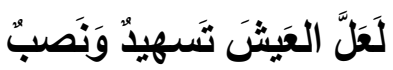

إذًا لقد حمله الزمن الإهانة وكلفه بها، وأما الحياة فهي كظلال وهمية لنبات قصير ، وبما أن الظل مؤقت، كان لان لان

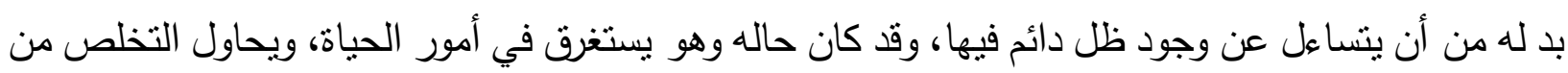

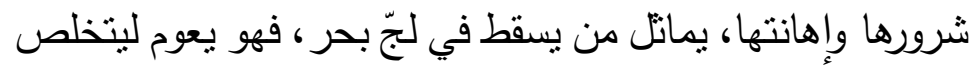
منه، وبما أنه لا يحسن العوم، يوشك أن يهلك، إن لم يتداركه من يستتقذه، والحياة شُشَبَّهُ بالبحر وأهلها بالراكبين في السفينة. ولذلك قال أبو بكر الصديق رضي الله عنه" :يا هادي الطريق إنما الفَجْر أَو البحر يقول ان انتظرت حتى يضيء

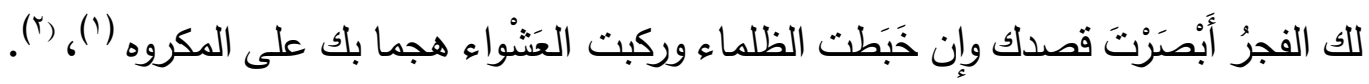

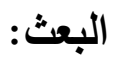

لم يظهر المعري في أنثعاره موققا واضحا لعقيدته في البعث، فنجده في موضع غير مطدئن إلى البعث حيث

ويدأب ناسك لرجاء بعث. (广) ()

علم فكيف إذا حوتنا الأقبر

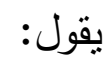

وظاهر أمرنا عيش وموت كما يبدي حيرته عن أحوال الروح بعد الموت ويقول: أرواحنا معنا وليس لنا بها لروحات بعات

(1) أبو أحمد حميد بن مخلا بن قتيبة بن عبد الله الخرساني المعروف بابن زنجويه (10 اهـ)، الأموال لابن زنجويه،

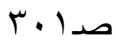

تحقيق الدكتور: شاكر ذيب فياض الأستاذ المساعد -بجامعة الملك سعود، الناشر: مركز الملك فيصل للبحوث والدراسات

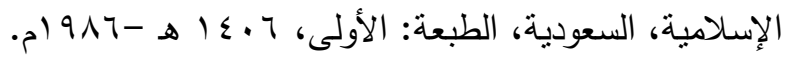

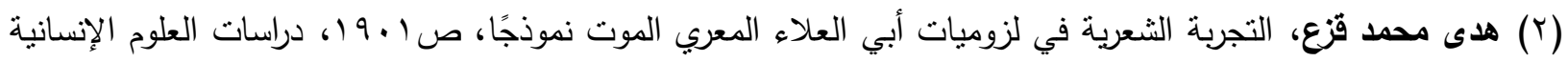

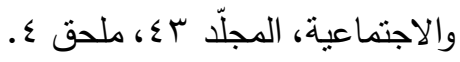

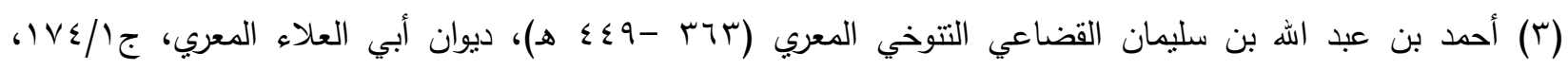


ويتحدث المعري عن اختلاف الناس في البعث ويراه أمراً شديد لا غموض وهو يضرب مثلا في نفي البعث

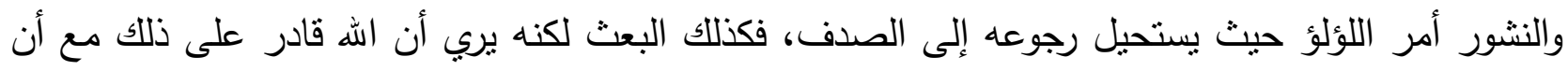
العقل عاجز عن إدراكه.

أما القيامة فالتنازع شائع فيها وما لخيبها إصحار

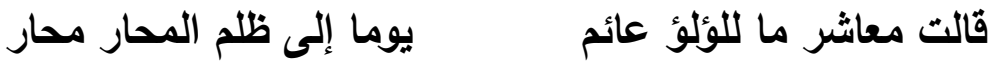

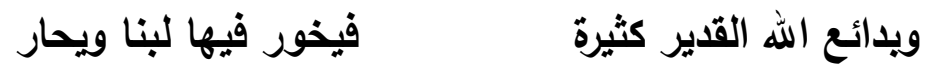

وفي موضع آخر يتمنى أن تظفر نفسه بالسعادة بعد البعث مع أن بين نفسه وبينه عهدا طويلا في البلى:

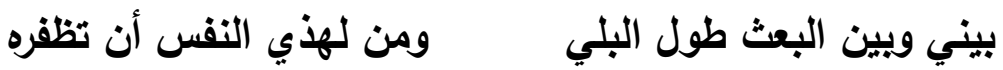

والله ينشر أرواحا بقرته

ويرى أن مرآة النجوم (العقل) ثبت الموت ولكنها لا تنبئ بالقيامة:

خد المرآة وإستخبر نجوما المر بمطعم الأري المشور

تلال على الحمام بلا ارتياب ولكن لا تلال على النشور

ثم يقول المعري: يقولون إن الميت بعد المكوث الطويل في القبر سيبعث شابا معافى ويسرح ويمح في جنات الخلد فما أجمل ذلك لو صح فشكه الساخر هنا لا يخفى بعد أن أنكر البعث في البيتين السابقين. (') المبحث الثالث: المدرسة الفكرية التي ينتمي إليها أبو العلاء المعري ونقدها وفق الروئية التريوية الإسلامية

الثثك عند أبى العلاء المعري

إنَّ آراء أبي العلاء في الحياة والإنسان هي رؤئً وأخيلةُ شاعرٍ تعبِّر عن وجدانه، وحالات نفسيته المتغيّرة

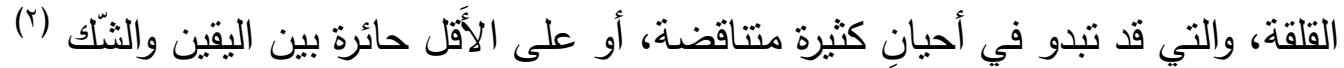
ما من باحث وقف عند صفات أبي العلاء وحياته وأدبه إلا ركز على جانب الحياة الحزينة عنده؛ وطفق يعلل

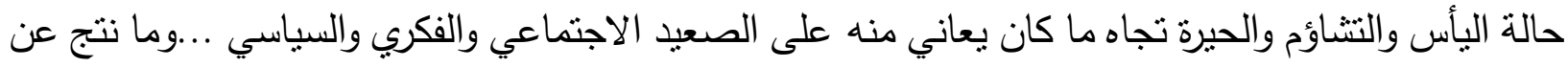
ذللك من فلسفة تأرجحت بين الثلك واليقين في عقيدنه؛ وبين رفض الهتمع وقبوله، وبين ما عانى منه من

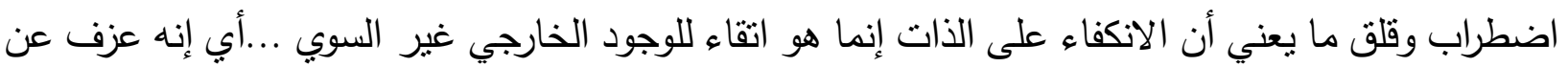

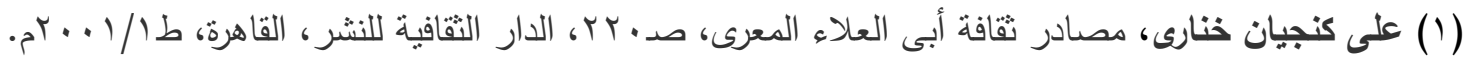
(r) حامد صادق قتيبي، قلق الحياة في أدب أبي العلاء المعري، صد آس، جامعة الإسراء الخاصة، نسخة إلكترونية، د ن. 
مخالطة الناس ورؤيتهم حتى يظفر بمعرفة أحوالهم وأخبارهم وأخبار الأمم والأقوام الذين سبقوهم؛ فهو ينقطع عنهم من جهة ويتصل بهم

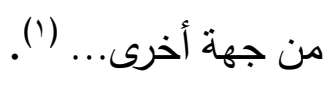

فالمعري يستشعر قوة خاصة، ما جعله يتجاوز عقدة العمى التي سقط فيها غير ما شاعر أصيب بفقد البصر ،

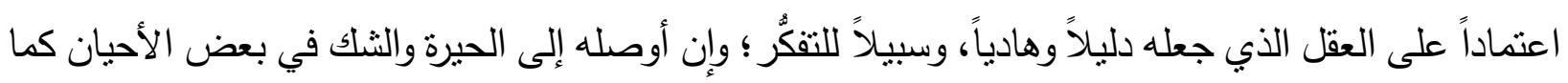
يعترف بقوله (r) - (ب).

سألت عقلي فلم يخبر وقلت له سلِ الرجال، فما أفتوا ولا عرفوا

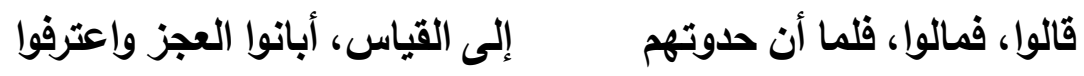

العقل في مواجهة النقل:

يطرح المعري قضية الألوهية بشيء من الإنكار تارة وتارة أخرى بشكل إيماني عميق، فالثنك يبدأ لديه في

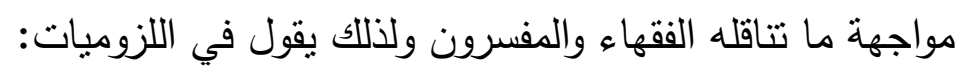

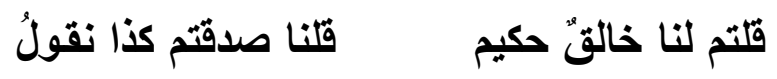

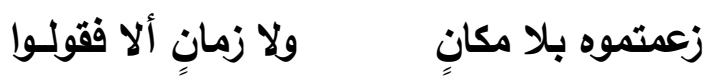

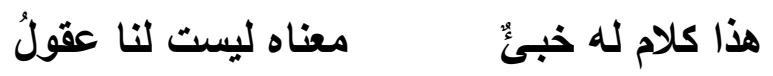
ويقول:

أما الإله فأمرّ لست مدركه فاحذر لجيلك فوق الأرض إسخاطا ويتعجب المعري لماذا لا يتألم الله لعذاب الناس:

لوانى كلب لاعترتني حمية لجروي أن يلقى كما يلقى الإنس

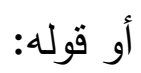

رأيت سجايا الناس فيها تظالم لا ريب في عل الذي خلق الظلما وأن هناللك تتاقضا في الأحكام فيخاطب اله قائلا:

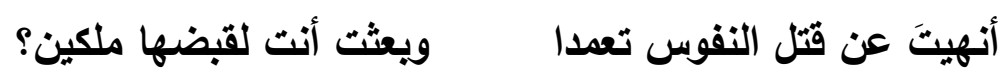

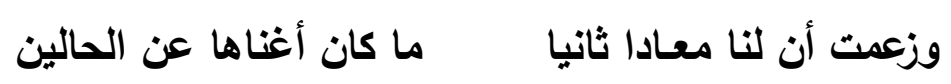
ويخاطب الله متسائلا: إن كان لا يحظى برزقك عاقل وترزق مجنونا وترزق أحمقا 


\section{فلا ذنب يارب السماء على امرئ رأى من ما يشتهي فتزندةا}

لكن الثك لديه يجعله مترددا بين الإيمان والكفر ولذا نفاجأ عندما نراه بردد:

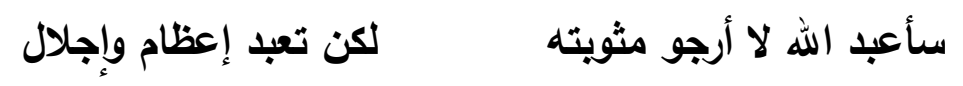

وعندما ينظر المعري في بعض أحكام الفقه يجد أن هنالك أحكاما لا يقبلها العقل منل حكم دية اليدإ إذإلها قطعت بخمسمائة دينار ذهب وإذا سرق أحد من الناس ربع دينار تقطع يده فيعترض فائلائا:

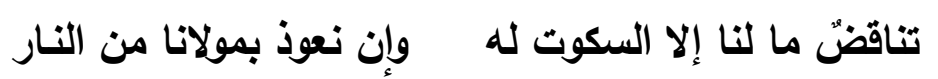

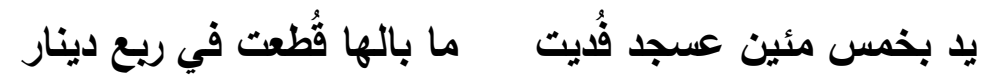

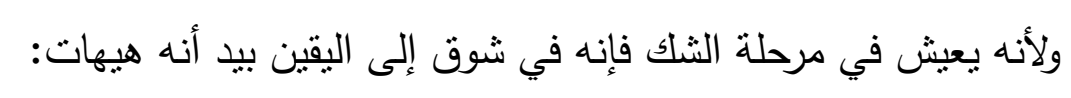

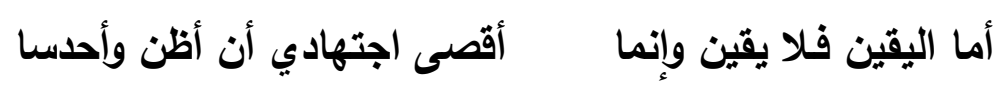
أو قوله:

\section{وقد عدم التيقن في زمان عصلنا من حجاه على التظني}

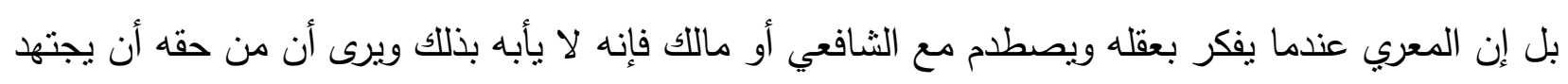
طالما هو قادر على التفكير

وينفر عقلي مغضبا إن تركته سدى وأتبعت الثافعي ومالكا ويفاجئنا المعري بأن العقل ينكر الأديان السابقة:

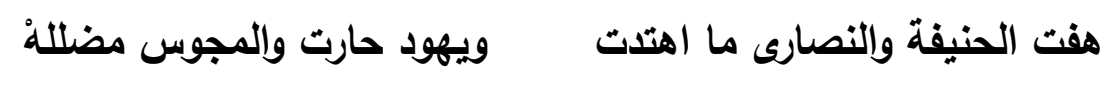

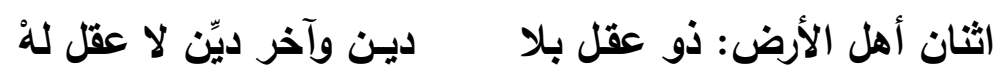

$$
\text { وينكر أن يكون آدم واحدا }
$$

وما آدم في مذهب العقل وإحد ولكنه عند القياس أو آدم

ويشكك المعري في تدين الناس من حوله ويرى أنه تدين منوارث وينشأ ناشئ الفتيان منـا

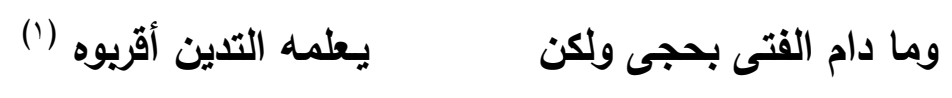




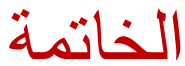

لقد اختلف الناس في عقيدة أبي العلاء المعري، "منهم من أمسكوا عن الجزم باتهامه، تحرجا، أو أشنكل

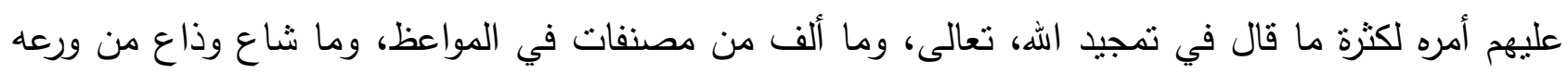
وتقواه وزهده، فاكتفوا بنقل أقوال من جرّحوه، ومعها أقوال من شهدوا له بصدي الهُ الإيمان وقوة اليقين.

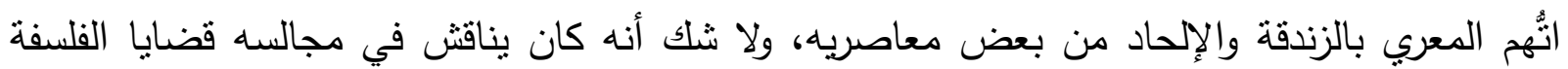
ويشرح للطلاب أشعاره ويفسر لهم ما صعب منها. وربما قاده الثرح إلى الحديث عن مختلف الآراء الفلسفية

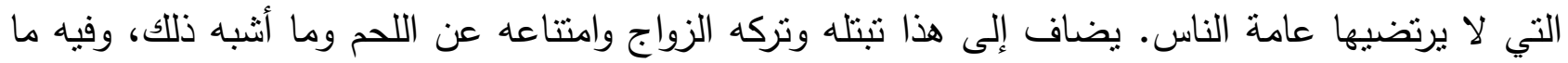
فيه من مجانبة لسنن الدين ولحوق بفلسفات برهمية هندية. وقد استتد متهوه إلى ما في رسالة الغفران من أخبار الزنادقة وأثنعارهم. أما أشعاره فيبين في بعضهانها ولهن الثنك والانكار .

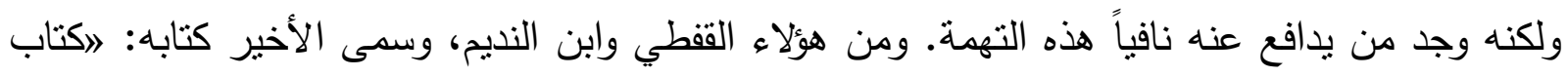
الإنصاف والتحري في دفع الظلم والتجري عن أبي العلاء المعري؛؛ وقال في مقدمته متحدثاء أناً عن حساده ومنتقديه: ارموه بالإلحاد والتعطيل، والعدول عن سواء السبيل، فمنهم من وضع على لسانه أقوال ملحدة ومنهم

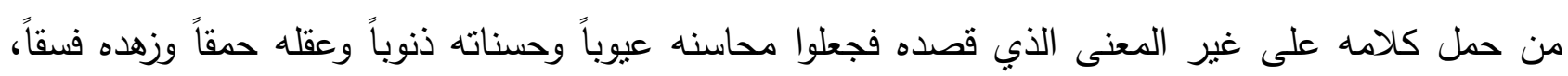

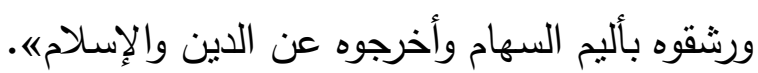

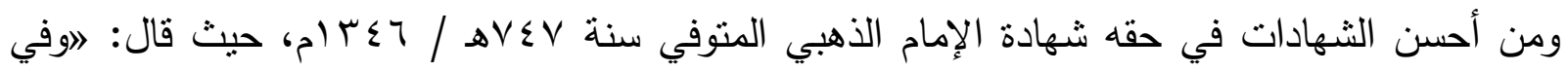

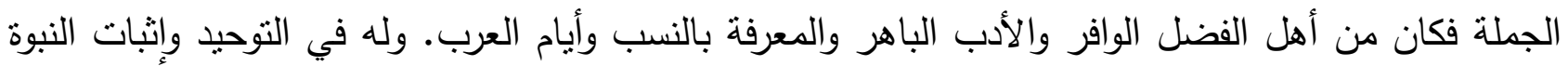
وما يحض على الزهد وإحياء طرق الفتوة والمروءة، شعر كثير والمشكل منه فله ـ على زعمه ـ تفسير هـ

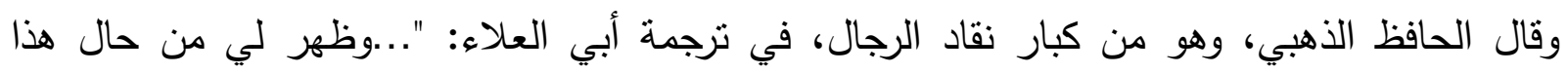
المخذول أنه متحير لم يجزم بنحلة....

وقال في ختام ترجمته: "...وما على الرجل أنسُ زهّاد المؤمنين، واله أعلم بما خُتم له."

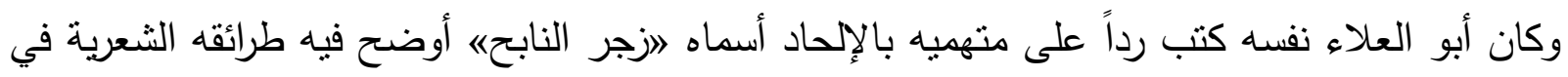
عرض آراء الفرق المختلفة، ومقاصده الأصلية من أثنعاره. وكثف في كتاب آخر أسماه 》الفصول والغاياته عن إيمانه بعذاب القبر والبعث والنشور ، وبكل ما له علاقة بعقيدة الأمة فيما يتصل بالغيب.

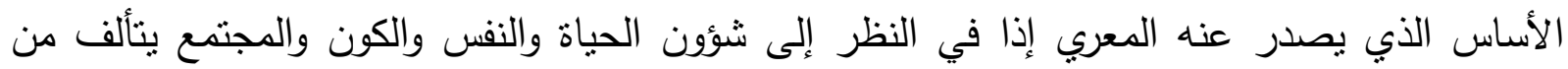
دعامتين مندمجتين متعاونتين:

السماحة بكل ما تقتضيه من رفق ومحبة وعدالة أريحية وما تفضي عليه من حب وتعاطف ونشاط وبذل مألتين

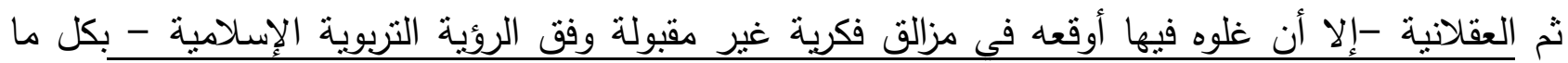


تقتضيه هذه العقلانية من هدوء وموضوعية وما بنجم عنها من تتظيم وتركيز وتوجيه للحياة إلا أن كل الأخطاء

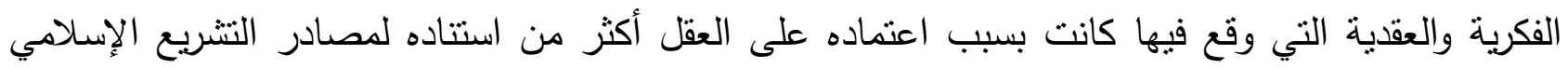
فمدرسته الفكرية بناء على ذلك هي مدرسة عقلية بحتة تقدم العقل على النقل، والرأي اعقلي على النص الصنى الصريح في غالب ما احتوته كتاباته.

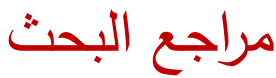

1- عمر بن أحمد بن هبة الله بن أبي جرادة العقيلي، كمال الدين ابن العديم ( •7 هـ)، بغية الطلب في تاريخ حلب، المحقق: د. سهيل زكار ، الناشر : دار الفكر ، د ت.

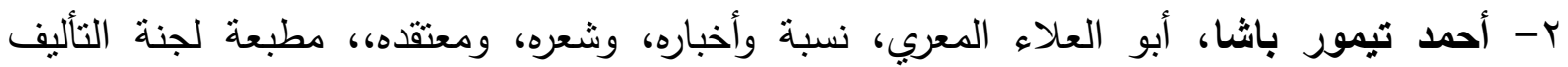

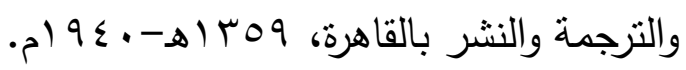

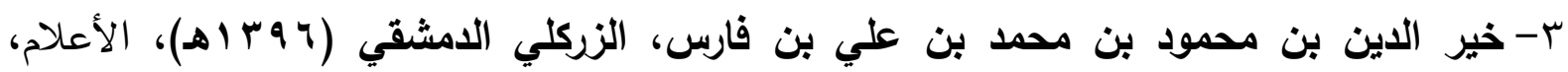

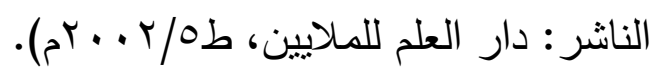

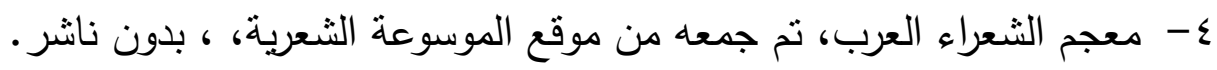

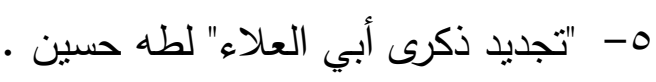
7- عبد العزيز الميمني الراجكوتي الأثري الهندي، أبو العلاء وما إليه، منشورات محمد على بيضون

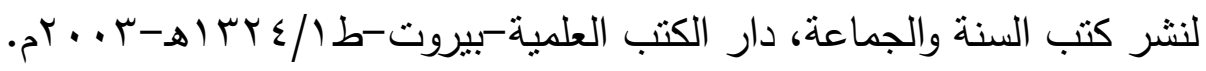

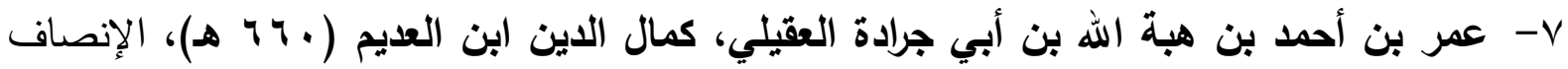

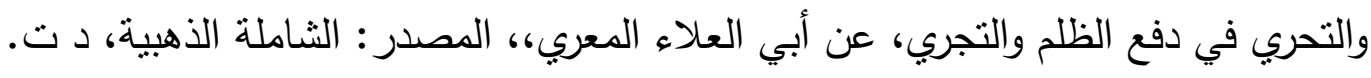

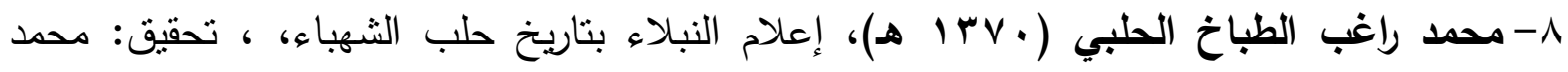

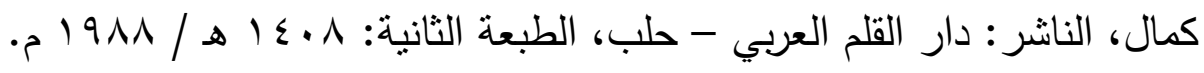

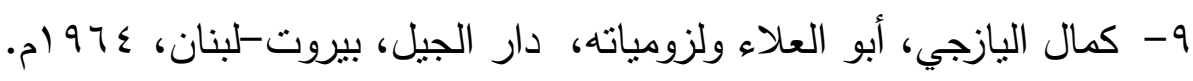

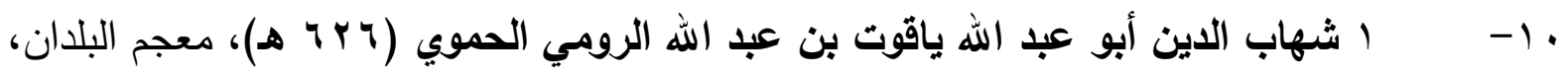
الناشر: دار الفكر - بيروت.

با r إ- إيهاب عبد الحميد عبد الصادق سلامة، شرحا أبي العلاء والخطيب التبريزي على ديوان أبي تمام دراسة نحوية صرفية، ، الناشر: رسالة ماجستير -كلية دار العلوم -جامعة القاهرة،

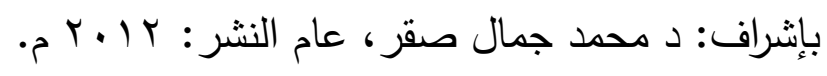


rا - أحمد يحيى علي محمد، المصطلحات البلاغية في شرح أبي العلاء لشعر المتنبي، أطروحة علمية قدمت لمجلس كلية الآداب في جامعة الموصل، وهي جزء من منطلبات نيل شهادة الدكتوراه،

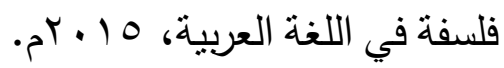

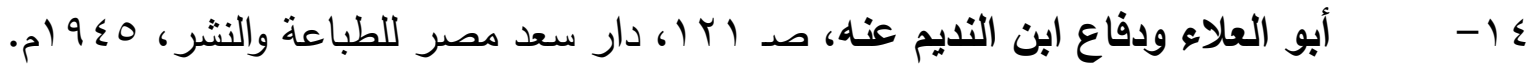

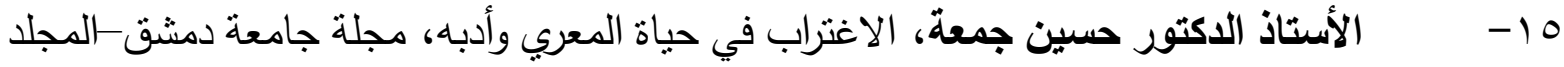

$$
\text { rV }
$$

17- (1) هنري لا وست، اختلاف الآراء في فلسفة أبي العلاء، المهرجان الألفي لأبي العلاء

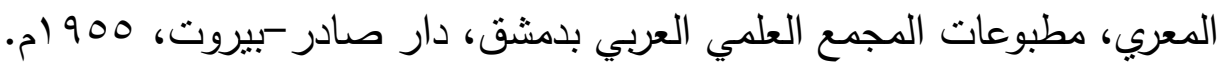

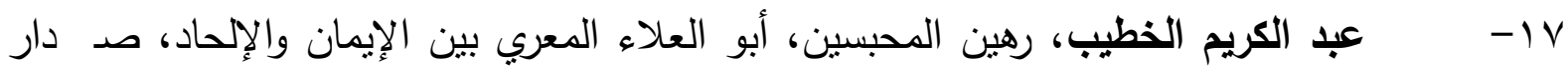

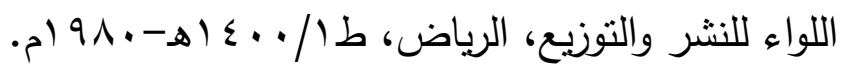

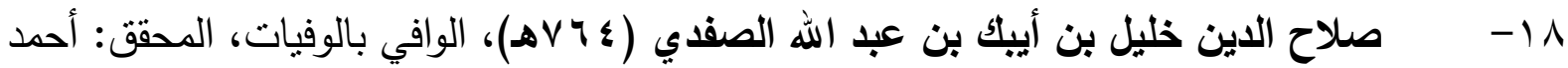

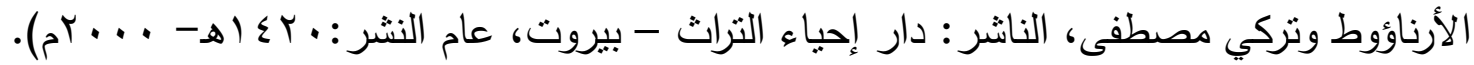

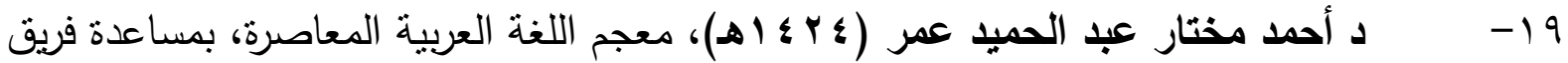

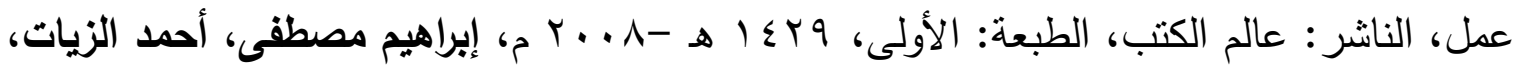

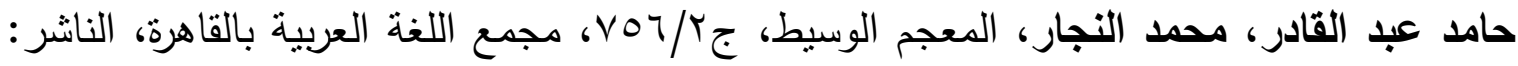

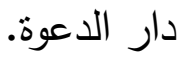

• ץ- - سلارة محمد عبد الله المعصوب القحطاني، دور ممارسة الألعاب في خفض القلق لذوي الإعاقات الجسدية الحركية بمؤسسة رعاية المشلولين بالطائف، رسالة ماجستير بكلية التربية بمكة

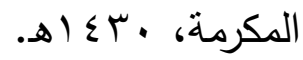

ا اY-

r T- رمضان محمود كريم البالاني، شعر المعري من منظور القراءة والتأويل، أطروحة رسالة علمية مقدمة إلى مجلس كلية التربية جامعة بغداد.

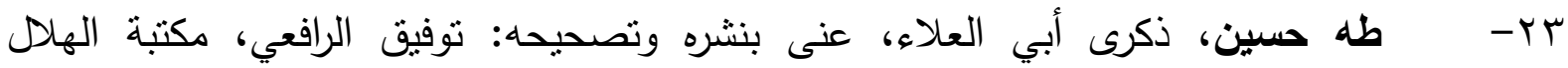

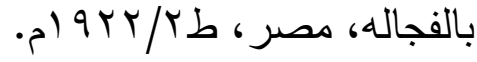
§ - - د. محمد أبو الفضل بلران، الثك عند أبى العلاء المعري، اجامعة الإمارات العربية

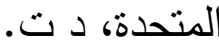


0Y- - إيهاب عبد الحميد عبد الصادق سلامة، شرحا أبي العلاء والخطيب التبريزي على ديوان

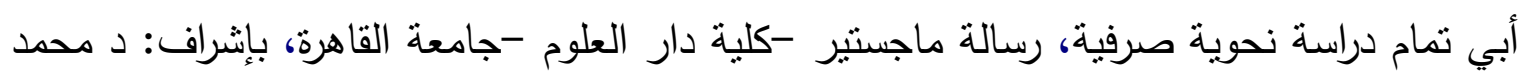

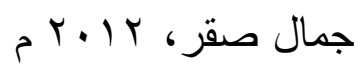

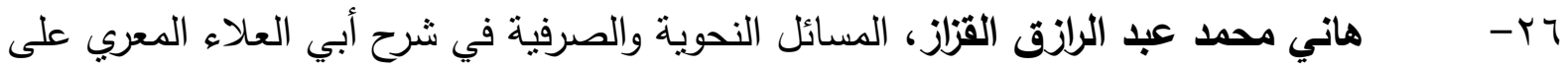

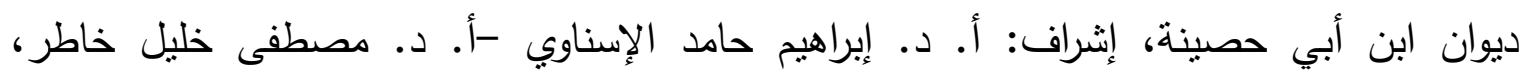
المصدر : الثاملة الذهبية

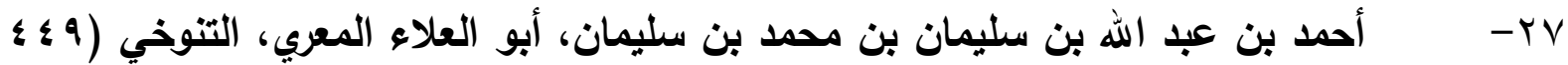
هـ)، رسالة الغفرانتحقيق: علي حسن فاعور، دار النشر: دار الكتب العلمية -بيروت / لبنان -

$$
\text { . }
$$

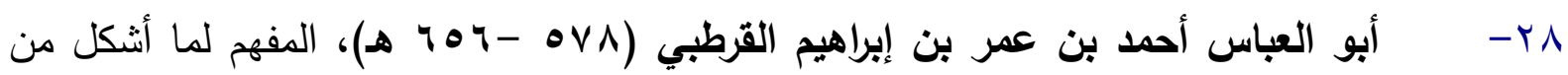
تلخيص كتاب مسلم، حقهه وعلق عليه وقدم له: محيي الدين ديب ميستو -أحمد محمد السيد يوسف علي بديوي -محمود إبراهيم بزال، الناشر : (دار ابن كثير، دمشق -بيروت)، (دار الكلم

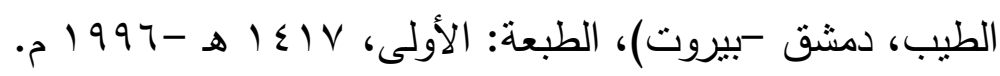

وץ- أبو أحمد حميد بن مخلا بن قتيبة بن عبد الله الخرساني المعروف بابن زنجويه

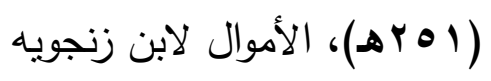

• ץ- تحقيق الدكتور: شاكر ذيب فياض الأستاذ المساعد -بجامعة الملك سعود، الناشر: مركز

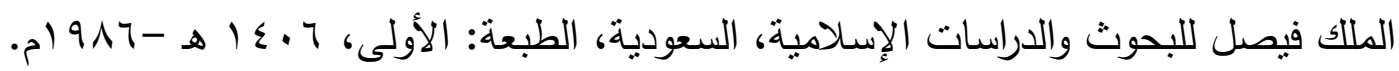

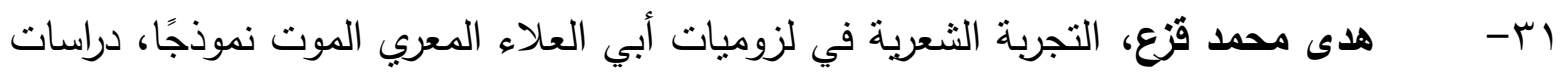

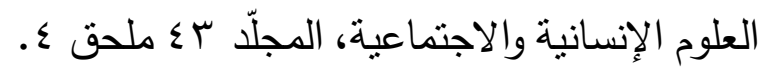
r T- - ملى كنجيان خنارى، مصادر ثقافة أبى العلاء المعرى، ، الدار الثقافية للنشر، القاهرة، . بس- حامد صادق قتيبي، قلق الحياة في أدب أبي العلاء المعري، جـامعة الإسراء الخاصة،

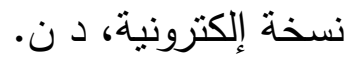

